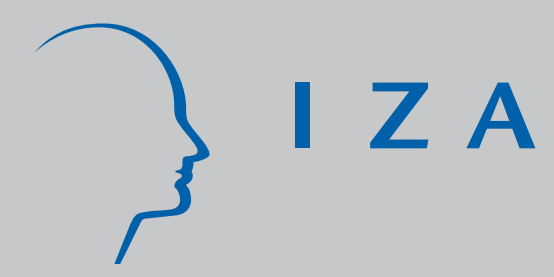

IZADP No. 1698

Dynamics and Diversity: Ethnic Employment Differences in England and Wales, 1991-2001

Kenneth Clark

Stephen Drinkwater

July 2005 


\title{
Dynamics and Diversity: Ethnic Employment Differences in England and Wales, 1991-2001
}

\author{
Kenneth Clark \\ University of Manchester \\ and IZA Bonn \\ Stephen Drinkwater \\ University of Surrey \\ and IZA Bonn
}

\author{
Discussion Paper No. 1698 \\ July 2005
}

IZA
P.O. Box 7240
53072 Bonn
Germany
Phone: +49-228-3894-0
Fax: +49-228-3894-180
Email: iza@iza.org

\begin{abstract}
Any opinions expressed here are those of the author(s) and not those of the institute. Research disseminated by IZA may include views on policy, but the institute itself takes no institutional policy positions.
\end{abstract}

The Institute for the Study of Labor (IZA) in Bonn is a local and virtual international research center and a place of communication between science, politics and business. IZA is an independent nonprofit company supported by Deutsche Post World Net. The center is associated with the University of Bonn and offers a stimulating research environment through its research networks, research support, and visitors and doctoral programs. IZA engages in (i) original and internationally competitive research in all fields of labor economics, (ii) development of policy concepts, and (iii) dissemination of research results and concepts to the interested public.

IZA Discussion Papers often represent preliminary work and are circulated to encourage discussion. Citation of such a paper should account for its provisional character. A revised version may be available directly from the author. 


\section{ABSTRACT \\ Dynamics and Diversity: Ethnic Employment Differences in England and Wales, 1991-2001*}

This paper uses microdata from the 1991 and 2001 Population Censuses to examine differences in the employment experiences of ethnic minorities living in England and Wales. It focuses on two main issues, firstly the extent to which the employment position of the main ethnic minority groups changed between the two Census dates and secondly, a detailed examination of employment amongst ethnic groups in 2001. In relative terms, it is found that there was an improvement in the employment rates of most ethnic minority groups over the period, some of which could be explained by enhanced levels of observable characteristics. However, the employment gap between Whites and certain ethnic minority groups remains extremely large. Religion, local deprivation and educational qualifications are important influences on employment for many of these groups.

JEL Classification: J15, J21, J7

Keywords: employment, ethnic minorities, discrimination

Corresponding author:

Kenneth Clark

School of Economic Studies

University of Manchester

Oxford Rd

Manchester

M13 9PL

UK

Email: ken.clark@manchester.ac.uk

\footnotetext{
* The authors acknowledge funding from the Joseph Rowntree Foundation. The support of the ONS, CCSR and ESRC/JISC Census of Population Programme is gratefully acknowledged. We are also grateful for comments received from members of the Census Research Access Board, Frances Forsyth, Derek Leslie and seminar participants at the CRONEM conference on the Future of Multicultural Britain at Roehampton University, the SARs User Group at the Royal Statistical Society and the Work and Pensions Economics Group Annual Conference at the University of York. The authors alone are responsible for the interpretation of the data. Census output is Crown copyright and is reproduced with the permission of the Controller of HMSO.
} 


\section{Introduction}

The 1990s witnessed a large decline in unemployment in the United Kingdom (UK). OECD statistics indicate that the UK unemployment rate fell from 8.6 per cent in 1991 to 5.0 per cent in 2001. This improvement was, in absolute terms, better than the OECD as a whole, where unemployment only fell from 6.8 per cent to 6.5 per cent (OECD, 2003). Some European countries fared particularly badly in comparison to the UK. For example, unemployment rates in Germany and Italy rose from 4.2 and 8.5 per cent to 7.8 and 9.5 per cent respectively between these dates (OECD, 2003). However, some sections of the UK population continue to suffer from high rates of unemployment, and increasingly from high rates of economic inactivity as well. These factors combine to generate low employment rates for certain ethnic minority groups, which is the focus of this paper.

The UK's impressive labour market performance can partly be explained by the more active labour market policy stance taken by the government, particularly after New Labour came to power in 1997. Policies such as the New Deal and Employment Zones were introduced with the aim of reducing the high levels of unemployment amongst certain at risk groups such as youngsters, as well as those in particular areas such as inner cities. Since ethnic minorities are on average younger than the majority White community and overwhelmingly reside in urban areas, New Labour's labour market policies would be expected to disproportionately affect the employment prospects of minority individuals of working age. For example, Department of Work and Pensions (DWP) data indicate that around 17 per cent of British New Deal for Young Persons participants are from the ethnic communities, which is roughly double their proportion in the population as a whole. In this paper we use Census microdata 
from 1991 and 2001 to investigate whether the employment position of ethnic minorities has improved relative to that of Whites. We proceed to conduct a detailed analysis of the diversity of ethnic minority employment rates for the most recent Census year.

There are a number of advantages of using Census microdata. First, we have access to large sample sizes so the position of narrowly defined minority groups can be investigated for both sexes without the need to pool data over time. Second, since Census microdata are now available for both 1991 and 2001 and the variable definitions are relatively consistent for these two years, we can also analyse changes over time. Thirdly, the 2001 data contain an enhanced set of covariates that could potentially add to our understanding of the differences between ethnic groups. For example, a question on religion was asked for the first time, which should be important for labour market outcomes, especially for females. In addition, the 2001 microdata contains better information on certain variables such as educational qualifications, children in the household and health than in 1991. The 2001 Census also asked a more detailed question on ethnicity, which allows us to identify different groups among the White community and a range of mixed race groups. Finally, the 2001 data contains a local authority identifier which means that the impact of spatial factors can be examined. These latter developments enable us to perform an in-depth analysis of the employment position of ethnic minority groups living in England and Wales in 2001.

The remainder of the paper is organised as follows. In Section 2, we review the previous literature on employment differences between the main ethnic groups living 
in the UK. This is followed, in Section 3, by a brief discussion of the data that we use in our analysis. Section 4 describes our analysis of the dynamics of ethnic employment difference using Census data from 1991 and 2001, while section 5 contains a detailed discussion of ethnic employment diversity in 2001. Section 6 concludes.

\section{Previous Literature}

Research into labour market differences between ethnic minority groups living in the UK has increased considerably over the past two decades. This can be explained by a range of factors. First, the ethnic minority population is expanding relatively quickly, as shown by Table 1, which reports that the percentage of the population of England and Wales accounted for by individuals from the ethnic communities increased from 6 per cent in 1991 to 9 per cent in 2001. Growth rates for some groups have been particularly large, for example, the Black African population more than doubled between 1991 and 2001. ${ }^{1}$ Note also the age structure of the ethnic minority groups compared to the White majority community. Black Africans, Bangladeshis and Pakistanis have relatively high proportions of their population in the 0-15 age category implying further growth in the population of working age from these groups in the future. Second, ethnic minority males and females have persistently suffered from labour market disadvantage, some of which has been attributed to discrimination, and this has partly driven the growth of interest from academics and policymakers in the welfare of ethnic communities in the UK. Finally, there has been an improvement in the quality and quantity of reliable data on ethnic differences in the labour market in recent years.

\footnotetext{
${ }^{1}$ The following section contains a discussion of the differences in the definition of ethnic group in the 1991 and 2001 Censuses. See also the Data Appendix.
} 
Early research was based on either specifically commissioned surveys or the General Household Survey (GHS). For example, Smith (1976) and Brown (1984) used the National Surveys of Ethnic Minorities, irregular surveys carried out by the Political and Economic Planning/Policy Studies Institute, to examine the relative employment prospects of various ethnic minority groups. Smith (1976) reported considerable ethnic differences in female employment rates. Three quarters of West Indian females aged 16-55 were found to be in employment, compared to 45 per cent of non-Muslim Asians, 18 per cent of Muslim Asians and an employment rate of 55 per cent in the population as a whole. In contrast, ethnic employment differences for males were much smaller, with West Indian and Asian males experiencing unemployment rates of less than 3 per cent in the early 1970s. Neither was Brown (1984) able to find substantial ethnic employment differences amongst males in the early 1980s since the employment rates for West Indians and Asians were found to be 64 and 68 per cent respectively, compared to 67 per cent for Whites. The pattern of labour market disadvantage now widely recognised to affect ethnic minorities is therefore a relatively recent phenomenon, beginning with the recession in the 1980s.

Until the early 1990s, the main government survey that could be used to study ethnic variations in the UK labour market was the GHS, especially if one wanted to analyse differences in earnings in addition to employment. However, this required researchers to pool several years of data together to achieve adequate sample sizes. Furthermore, the GHS only identified individuals as being White or Non-White until 1983, which further restricted the research that it was possible to carry out. Blackaby et al. (1994) considered the employment position of ethnic minorities (Non-Whites) as a whole 
relative to Whites using the GHS. They found that the employment position of ethnic minority males worsened in the 1980s compared to the 1970 s, since the employment disadvantage suffered by ethnic minorities increased from 2.6 percentage points in the 1970s to 10.9 percentage points in the later period. Using decomposition analysis they found that differences in observable human capital and other characteristics typically explained around a half of these differences.

However, during the 1990s, advances in data availability expanded the range of research possibilities. The Labour Force Survey (LFS), which although had been in existence since 1975, became an extremely useful resource for labour market researchers after it became quarterly in 1992, since this increased the potential sample sizes and made it easier to pool the data. The LFS also introduced an earnings question at the end of 1992, thus allowing more comprehensive analysis of ethnic earnings disparities than possible with the GHS because of larger sample sizes. Crucially, these improvements enabled researchers to compare separate ethnic groups, rather than treating Britain's Non-Whites as a homogenous bloc or blocs. This advance led to the recognition that differences between separate ethnic groups in their labour market outcomes were often greater than those between Whites and ethnic minorities as a whole.

An ethnicity question was asked in the Census for the first time in 1991. The 1991 Census also saw the release of a sample of Census records, known as the Sample of Anonymised Records (SARs). The SARs consisted of a random sample of 2 per cent of Census returns, which allowed for analysis of the smaller ethnic groups, as well as the ability to make comparisons by gender. One disadvantage of Census data in the 
UK, however, is that they contain no information on earnings. This restricts analysis of the full range of labour market outcomes.

The larger sample sizes in the LFS and SARs have enabled recent studies to consider the position of different ethnic minority groups living in the UK in much greater detail. For example, Blackaby et al. (1997) used the 1991 SARs to examine unemployment differences between nine ethnic minority groups (Black Caribbeans, Black Africans, Black Other, Indian, Pakistani-Bangladeshi, Chinese, Other Asian, 'Other Other' and Irish) by males and females, whereas Blackaby et al. (1999) used pooled LFS data from 1987 to 1991 to analyse variations in unemployment between White males and three minority groups: West Indians, Indians and Pakistani/Bangladeshis. Both studies applied Oaxaca-type decompositions and found that, for most groups, a large part of the differentials between Whites and the ethnic groups remained unexplained after controlling for the main personal and household characteristics. Blackaby et al. (1999) reported that the unemployment differential between White and Pakistani/Bangladeshi males was 14 percentage points, virtually none of which could be explained by characteristics differences. The variation in unemployment between White and West Indian males was 8.6 percentage points, whereas Indian males had a 2.6 percentage point higher unemployment rate than their White counterparts, despite having better characteristics, suggesting discrimination at the hiring stage against this group. By examining more detailed information on ethnic groups, Blackaby et al. (1997) were able to establish that of the Black groups, it was Black Africans, and the Black Other group to a lesser extent, who were particularly susceptible to unemployment. In contrast, it was found that Chinese males and females experienced very similar unemployment rates to Whites. 
However, both of these studies focus on unemployment, whereas it may be more meaningful to investigate employment differences because of the low rates of economic activity amongst some ethnic minority groups, especially Pakistani and Bangladeshi females. Moreover, inactivity rates have also increased for older males (Disney, 1999). Blackaby et al. (1998) decomposed employment differences between White males and three ethnic minority groups (Blacks, Indians and Pakistanis), as well as minorities as a whole, using 11 quarters of pooled Labour Force Survey (LFS) data from the early/mid 1990s. After estimating probit models, they report considerable differences between the groups, with Indian males having only a slightly lower employment rate than Whites, whilst the employment rate differentials with Blacks and Pakistanis were around 19 and 13 percentage points respectively. Around a half of these differences could be attributed to differences in characteristics. ${ }^{2}$ The difference between the employment rate of Whites and All Ethnic Minorities was 9.8 percentage points, of which 56 per cent was due to differences in characteristics.

Blackaby et al. (2002) extended this analysis by taking account of whether an individual attained their schooling in the UK or abroad and by considering the differences between native Whites and ethnic minorities. ${ }^{3}$ The difference in employment rates between native and immigrant ethnic minorities was 14 percentage points, less than 20 per cent of which could be explained by differences in characteristics, suggesting that native ethnic minorities have made little progress in

\footnotetext{
${ }^{2}$ The explanatory variables used in the probit equations are age, region, housing tenure, marital status, (number of) dependent children, qualifications, immigrant, year of arrival, year of interview, health and children of preschool age.

${ }^{3}$ Otherwise, very similar results are obtained to Blackaby et al. (1998) given that the same three minority groups are focused upon and their sample is only slightly different given that 13 quarters from the mid 1990s are analysed.
} 
closing the employment gap and as a result, hiring discrimination cannot be ruled out. This issue is analysed in greater detail in Blackaby et al. (2005).

Other studies have focused on specific aspects of unemployment/employment differences between ethnic groups. ${ }^{4}$ For example, given that a large, although declining, proportion of ethnic minorities are immigrants then the poor labour market performance of some of the ethnic minority groups may be explained by their relative lack of English language skills (Dustmann and Fabbri, 2003; Leslie and Lindley, 2001; Shields and Wheatley Price, 2001). Fritjers et al. (2003) examined whether the job search methods employed by immigrants are different to those used by natives because of factors such as the lack of fluency in the English language. Similarly Battu et al. (2004) focused more explicitly on ethnic differences in job search methods. An alternative strand of research has conducted audit studies whereby applicants, similar in all characteristics except their race, have applied for jobs or services such as insurance (Daniel, 1968; Commission for Racial Equality, 1996). Such studies have provided very direct evidence of racial discrimination.

Ethnic minority groups also tend to be concentrated in particular geographic areas (Clark and Drinkwater, 2002). Given that these are typically poor inner city areas, there may be lower levels of labour demand in such areas. These problems may be exacerbated by the fact that some ethnic minorities have oppositional identities (Battu et al., 2003) or a taste for isolation (Blackaby et al., 1999). Thomas (1998a) investigated the lower willingness to commute of ethnic minorities using the Survey of Incomes In and Out of Work. He estimated that the relative reluctance of non-

\footnotetext{
${ }^{4}$ Wheatley Price (2001a; 2001b) examines employment and unemployment differences between immigrants and natives rather than focusing on ethnic variations.
} 
Whites to commute over long distances accounted for around 20 per cent of their excess unemployment spells in comparison to Whites. Thomas (1998b) used the same dataset to determine whether higher ethnic minority unemployment is due to differences in attitudes towards work. However, he found no evidence in favour of this view since ethnic differences in unemployment spells actually widen after the inclusion of the attitudinal variables. Lindley (2002) examined the links between labour market activity, religion and ethnicity. She found that of those from the ethnic communities, Muslims suffered a considerable employment disadvantage relative to non-Muslims and that only around a half of this differential was due to characteristic differences.

In the remainder of the paper we extend the existing literature by explicitly considering the dynamics of ethnic employment disadvantage in England and Wales over the period 1991-2000. Prior to the release of the 2001 Census data it was difficult to examine changes in employment over time for meaningful samples on an ethnically disaggregated basis, using a consistent definition of ethnicity. We further extend previous research by considering the diversity of ethnic employment disadvantage using the more detailed information available in the 2001 sample of microdata. In particular, we are able to achieve a finer breakdown of ethnicity and to consider the impact of religion and local levels of deprivation on the employment performance of ethnic groups. The next section describes the data.

\section{Data}

The ensuing empirical analysis makes use of microdata from the Population Censuses that took place in Great Britain in 1991 and 2001. Census microdata, unlike other 
surveys of the population, provide relatively large samples of individuals from ethnic minority groups. Datasets such as the LFS or GHS contain only small numbers of Non-White individuals in any given period and several waves must be pooled to achieve reasonable sample sizes. As Section 2 demonstrated, considerable labour market differences exist between different ethnic minority groups, thus necessitating sample sizes which allow analyses that are specific to individual groups to be conducted. Census microdata, known as the SARs in 1991 and Controlled Access Microdata (CAMs) in 2001, are a 2 per cent sample of returns in 1991 and a 3 per cent sample in 2001, allowing us to analyse all ethnic groups, as well as males and females, separately. Note that we study England and Wales because different ethnicity questions were asked in Scotland and Northern Ireland in 2001.

The 2001 Census ethnicity question was different to that asked in 1991 hence in our comparison of employment rates across time we need to find a definition of ethnicity which is relatively constant across the period. In an authoritative study, Simpson and Akinwale (2004) exploit the Office of National Statistics Longitudinal Study of England and Wales (LS) to examine changes in individual reported ethnicity between 1991 and 2001. ${ }^{6}$ They find that there are seven clearly defined groups which are relatively stable over the period - White, Caribbean, African, Indian, Pakistani, Bangladeshi and Chinese. ${ }^{7}$ Thus we focus on these seven groups, as well as ethnic minorities as a whole, in our comparisons of the 1991 and 2001 data. We

\footnotetext{
${ }^{5}$ There are also differences in the religion question asked in these two countries and in the educational question asked in Scotland in 2001. Moreover, the ethnic minority populations in each of these countries is small, with 2.01 per cent of the Scottish and 0.75 per cent of the Northern Irish populations from the ethnic minorities in 2001. Both of these amounts are lower than the percentage of ethnic minorities in the Welsh population (2.14 per cent). 9.08 per cent of residents in England were from the ethnic communities in 2001, ranging from 2.31 per cent in the South West to 28.86 per cent in London.

6 The LS contains, inter alia, information on the Census returns for the same individuals for approximately 1 per cent of the population of England and Wales since 1971.

7 In fact Simpson and Akinwale (2004) also include an 'Other' category making an 8-way classification but the 'Other' category dropped from our timewise comparison as it has no clear interpretation.
} 
subsequently analyse the more detailed 2001 data using a finer breakdown of ethnicity which allows us to identify 16 groups.

Table 2 contains some information on the sample sizes and labour market status of the seven consistently defined groups for males and females in 1991 and 2001. We report activity and unemployment rates as well as employment rates (measured over the economically active population) including and excluding students. While our total sample is large (over 315,000 males in 1991 and half a million in 2001 reflecting the larger sample of microdata selected from the 2001 Census) the fact that the ethnic minority population is small is reflected in the varying sample sizes for the individual groups. Nevertheless one year of LFS data would typically contain no more than a hundred Bangladeshi males compared to over 900 in the 1991 Census microdata.

The data in Table 2 on the labour market status of the main ethnic groups show that, although the absolute position of ethnic minorities improved between these two dates, large differences between groups remained, particularly in relation to Whites. ${ }^{8}$ For example, the unemployment rate for all ethnic minority males and females was still in excess of 10 per cent (13.2 and 11.1 per cent respectively) in 2001, compared with 5.8 per cent for White males and 4.3 per cent for White females. Despite the substantial decrease in joblessness over this period, unemployment rates in 2001 remained in excess of 16 percent for Black Caribbean males and for males and females from the Black African, Pakistani and Bangladeshi groups.

\footnotetext{
${ }^{8}$ The precise definitions of the measures of labour market activity can be found in the Data Appendix.
} 
Pakistani and Bangladeshi females continued to have very low economic activity rates: combine this with high unemployment and the employment rates for these groups were less than 30 per cent in 2001, even after the exclusion of students. The comparable employment rates for White and Black Caribbean females were over 70 per cent. Relatively low employment rates were also observed in 2001 for Pakistani and Bangladeshi males, even after the removal of students. This contrasts with the situation for Chinese males for whom the exclusion of students implies that they have the highest employment rate. Given that this group displays a relatively low activity rate, this highlights the high proportion of Chinese males of working age who are currently in full time education. The employment rate for Chinese females is also much higher when students are removed. A similar effect is observed for Indian males but it is not as pronounced as it is for the Chinese.

In the subsequent econometric analysis we focus on the employment rate where fulltime students are removed from the numerator and denominator. We choose to focus on employment rates because of the large amount of inactivity amongst certain groups, particularly Pakistani and Bangladeshi females (Dale and Holdsworth, 1997) and also amongst older males (Disney, 1999). A comparison of unemployment rates would fail to account for the economically inactive. Partly for this reason high employment rates are a target for policymakers in the UK and European Union. For example employment rates are the focus of the UK government's labour market policy towards ethnic minorities, and more generally through its endorsement of the European Union's Lisbon Strategy (DWP, 2001, 2004). Previous research has also noted how, in the context of racial discrimination in the UK labour market, barriers to entry to the labour market are likely to be more important than other forms of 
discrimination, such as in the payment of wages, since discrimination at the hiring stage is potentially less easily observed than wage discrimination (Leslie, 1998). Furthermore given that, compared to Whites, ethnic minorities are more likely to stay on in post compulsory education (Leslie and Drinkwater, 1999), deferring their labour market entry in anticipation of enhanced future earnings and employment opportunities, we also report employment rates after excluding students from the denominator. ${ }^{9}$ This is done because the majority of students are not active in the labour market, which implies that the inclusion of students would reduce the employment rate considerably for some ethnic minority groups. This is evident from Table 2 where there are some differences in employment rates are in excess of twenty percentage points depending on whether students are included or not.

\section{Ethnic Employment Dynamics: 1991-2001}

Table 3 highlights the dynamics of ethnic employment disadvantage over the period by reporting the difference-in-differences in economic outcomes for each ethnic minority group compared to Whites between 1991 and 2001. These were calculated using the formula:

$$
\left(Y_{01}^{j}-Y_{91}^{j}\right)-\left(Y_{01}^{w}-Y_{91}^{w}\right)
$$

where the $Y^{\prime}$ s denote the outcome (rate) in question. The $w$ superscript refers to Whites while the $j$ superscript refers to the comparison ethnic minority group.

Whilst this is merely an alternative method of presenting the data in Table 2, the difference-in-differences emphasise the performance of each group relative to Whites.

\footnotetext{
9 Full-time students are also removed from the numerator in 2001 since some are recorded as economically active. Please see the Data Appendix for further details.
} 
Note that economic activity for all ethnic minorities fell compared to Whites between 1991 and 2001, partly reflecting the increasing proportion of students among the ethnic minority groups. However, Black African males bucked this trend by showing a large increase in activity rates. Ethnic minority males and females saw their unemployment rates fall more rapidly than Whites, with particularly noteworthy reductions for Black Africans, Pakistanis and Bangladeshis. Whereas employment rates improved for ethnic minorities as whole relative to Whites for males, the opposite was true for females. This was mainly due to the relatively small increases in employment experienced by Black Caribbean and Chinese females.

Focussing on our preferred measure of employment, it is clear that the relative improvement for males was statistically significant for all ethnic minority groups except the Chinese. For females, there was a significant decline in the relative employment rate for Caribbeans, a significant increase for Indians, with the other differences-in-differences insignificantly different from zero. Whilst statistical significance is important we should not lose sight of the economic significance of the results in Table 3: difference-in-differences of over 10 percentage points in employment rates are substantial changes in the relative labour market performance of different groups of workers. The magnitude of these shifts emphasises the importance of understanding ethnic employment patterns.

To analyse these changes in further detail we estimated a series of probit models where the dependent value took the value one if the individual was employed and zero otherwise. To fully account for ethnic differences in access to employment, separate probit equations were estimated for each of the seven ethnic groups described in 
Table 2, for each sex and for each year of Census microdata. We controlled for the following variables: age and its square, marital status, whether there were dependant children in household, whether the respondent had higher qualifications (defined here as any post-school qualification), country of birth, limiting long term illness and region. ${ }^{10}$ Note that the Census did not collect data on English language ability or, for immigrants, the year of arrival in the UK. ${ }^{11}$

The primary purpose for estimating these models is to use the coefficients as inputs within a decomposition procedure; in the interests of brevity we do not report the coefficient estimates from each equation. Instead, to give a flavour of the results, Tables A1 and A2 in the Appendix contain the estimates of pooled probit models containing dummy variables for each ethnic group. The signs of the estimated coefficients in the pooled models are broadly consistent with expectations and previous research. The employment probability is increasing in age, but at a declining rate and education (captured here by a dummy for higher qualifications) improves employment outcomes. There is a strong marriage premium for males in both years, whilst for females, the significantly negative effect in 1991 becomes a weak positive effect after controlling for other influences in 2001, relative to being single. Those with limiting long-term illnesses have substantially lower employment probabilities and the UK born have significantly higher employment rates compared to immigrants. Region of residence also impacts on employment as we would expect. Even after controlling for observable characteristics, however, there are significant employment differences between Whites and the minority groups. The only groups which did have

\footnotetext{
${ }^{10}$ Further information on the construction of these variables can be found in the Data Appendix.

${ }^{11}$ The only language information available in the Census for England and Wales is the ability to speak, read and write Welsh in Wales. English language ability may also be less important now because of the lower proportion of ethnic minorities who were born overseas and changes in immigration policy.
} 
not significantly lower employment rate than Whites at the 5 per cent level were Indian and Chinese females in 1991. Note that Black Caribbean females were more likely to be in employment than Whites in 1991 and 2001 after controlling for other characteristics.

Tables 4 and 5 present the results of using the estimated probit coefficients in the following decomposition ${ }^{12}$ :

$$
\hat{E}^{w}-\hat{E}^{j}=\left\{\bar{P}\left(x^{w} \hat{\beta}^{*}\right)-\bar{P}\left(x^{j} \hat{\beta}^{*}\right)\right\}+\left\{\left[\bar{P}\left(x^{w} \hat{\beta}^{w}\right)-\bar{P}\left(x^{w} \hat{\beta}^{*}\right)\right]-\left[\bar{P}\left(x^{j} \hat{\beta}^{j}\right)-\bar{P}\left(x^{j} \hat{\beta}^{*}\right)\right]\right\} .
$$

Here $\hat{E}^{w}$ is the average of the predicted employment probabilities for Whites and $\hat{E}^{j}$ is the same for the ethnic minority group $j . \hat{\beta}$ is the vector of estimated coefficients from the probit model and $\hat{\beta}^{*}$ is a vector of estimated coefficients from a probit model estimated on a pooled sample (Whites and the ethnic minority comparison group), $\bar{P}\left(x^{j} \hat{\beta}^{j}\right)$ is the average of the fitted probabilities from the probit model estimated using the observations in group $j$ and the estimated coefficients from group $j$ and so on. The first term in the braces is the component of the probability difference due to observed characteristics, while the second term in braces is the effect of coefficients which corresponds to unobservable, group-specific influences on the employment probability. The decomposition allows us to estimate what proportion of the difference between any ethnic minority group and the White majority is due to differences in observed characteristics. The remaining "unexplained" component may reflect differential treatment by the labour market such as employer discrimination, or cultural/ethnic differences in motivation or preferences between groups.

\footnotetext{
12 This decomposition is based on Gomulka and Stern (1990), as implemented in Blackaby et al. (2002). This is basically an extension of the Oaxaca (1973) decomposition to the case of a binary dependent variable.
} 
The results of applying equation (2) to the employment differential between White males and the male members of the six other consistently defined ethnic groups for 1991 and 2001 are reported in Table 4. Table 5 reports the equivalent information for females. In the tables a positive entry indicates an advantage for Whites over the respective ethnic minority group thus the first row confirms that in 1991 there were large employment differentials between White males and their counterparts from each of the other groups, apart from Indians and Chinese, in 1991. The Chinese were actually very slightly more likely to be in employment in 1991, which is entirely due to this group possessing greater employment enhancing characteristics relative to Whites since these characteristics were less well rewarded in comparison. Indian males also possessed better characteristics than Whites but this was more than outweighed by lower rewards to these characteristics, producing a 2.4 percentage point lower employment rate compared to White males. The difference in employment rates between Pakistani and Bangladeshi males and Whites was more than 20 percentage points, a clear majority of which was unexplained by characteristic differences. Males from the two Black groups also experienced far lower levels of employment than Whites. Again, very little of the differential between Whites and Black African males could be accounted for by characteristic differences, while for Caribbeans around half of the differential was explained.

The bottom panel of Table 4 shows that the relative position for males from each of the minority groups improved between the two Censuses. However, the extent of these improvements varied. While Black Africans, Pakistanis and Bangladeshis experienced fairly large falls (in percentage point terms) in their employment differential relative to Whites, this was not the case for Black Caribbeans. For the two 
most successful minority groups, the small differential between Indians and Whites that existed in 1991 had further narrowed, whilst the Chinese extended their modest employment advantage over Whites between the two dates. The improvement in the relative employment prospects of Black Africans can be attributed to the possession of better characteristics than Whites in 2001; the characteristics component also fell for both Pakistanis and Bangladeshis.

This characteristics component of the decomposition can be further broken down into its constituent parts using a technique described in Even and MacPherson (1993) and the results of this are also presented in Tables 4 and $5 .{ }^{13}$ Age accounts for some of the improvement, especially for Bangladeshis, whilst a larger proportion of Pakistanis and Black Africans possessed higher qualifications than Whites in 2001. These factors had an offsetting impact on the much higher proportion of immigrants amongst the ethnic minority groups which tends to reduce the employment probability.

Further evidence of the enhanced endowments of characteristics possessed by ethnic minority males can be found in Table 6 which reports mean levels of key characteristics for 1991 and 2001. There were particularly large increases in the percentage of Black African and South Asian males with higher qualifications. Leslie and Drinkwater (1999) identified the high proportion of ethnic minority individuals from these groups in higher and further education in 1991 and it is the movement of these cohorts into the labour market which helps to explain the improvement in the employment prospects of these groups and the relatively poorer performance of the Black Caribbean group, where educational participation is lower. In line with

\footnotetext{
${ }^{13}$ The interested reader can find the formula for this breakdown in Blackaby et al. (2002).
} 
increasingly strict regulations on who can enter the UK, there was a general decline in the percentage of immigrants in our sample of these ethnic groups. Insofar as immigrant status reduces employment prospects, this contributes to reductions in the employment gaps with respect to the White group. While there was an increase in the proportion of Black African immigrants, this was more than offset by more favourable levels of other characteristics.

Table 5 reports that the position for females is somewhat different. First, Black Caribbeans enjoyed a higher employment rate than Whites in 1991, despite having lower endowments of employment enhancing characteristics. A potential explanation is that this group of women have higher proportions of single individuals and are thus under greater pressure to find employment as the sole earner in the household (Holdsworth and Dale, 1997). Second, the employment rate of White females was higher than that of all other groups in 1991, with the advantage over Pakistanis and Bangladeshis being particularly large. For both of these groups, the differential with Whites was more than 45 percentage points, less of than a half of which could be explained by endowments of characteristics. In contrast to males, Chinese females had lower levels of employment than Whites, whilst the gap between Indian and White females was also greater than it was for males, with characteristics explaining most or all of the employment differences between these two groups and Whites in 1991.

For females there was less convergence over time in the employment rates of Whites and ethnic minorities than was observed for males. Black Africans and the South Asian groups did see some narrowing of the employment deficits with Whites but 
these reductions were small. Furthermore, unlike for males, this is not so much the outcome of rising endowments of employment-enhancing characteristics. For instance, while the explained component fell for each of the South Asian groups, it remains positive and fairly large in each case. As Table 6 shows, although the percentage of Pakistani and Bangladeshi females possessing higher qualifications increased substantially between 1991 and 2001, they still lagged behind White females. The reduction in the contribution of the characteristics component for Indian females was due to this group having experienced a very large increase in the proportion with higher qualifications and also a reduction in the proportion with dependant children.

\section{Ethnic Employment Diversity in 2001}

In the preceding section we examined the relative employment experience of six ethnic minority groups using Census data from 1991 and 2001. In this section we use some of the additional information available for the first time in the 2001 Census to augment the analysis. In particular we use the more detailed breakdown of ethnicity to describe the employment position of a larger set of ethnic groups and we examine the impact of religion, qualifications and local area effects on the employment rates of these ethnic groups.

To set the scene, Table 7 reports labour market activity, using the same definitions as Table 2, by narrow ethnic group for the 2001 sample. This represents the most ethnically disaggregated information that is available for the working age population of England and Wales. In particular, it allows those of mixed ethnicity to be 
identified, separates Whites into three groups and provides a more useful breakdown of the 'Other' group than previously available.

Despite the general reduction in unemployment rates over the 1990s, Table 7 shows that, allied to the earlier analysis, male unemployment rates were in excess of 10 per cent in 2001 for all ethnic minority groups apart from Indians, Chinese and the Mixed: White \& Asian group. Furthermore, unemployment rates were in excess of 20 per cent for Bangladeshi males and males identifying themselves as Mixed: White \& Black African. The employment rates of some of the Mixed groups are particularly low, with just over a half of Mixed: White \& Black Africans in employment and less than two-thirds of this group in employment even after the exclusion of students. White Britons had the highest employment rate of the White groups, with White Irish experiencing relatively low levels of employment after the exclusion of students. Again the importance of excluding students from the employment rate is demonstrated here. In addition to those groups already discussed in Table 2, the employment rate discrepancy when students were excluded was in excess of 10 percentage points for Mixed: White \& Asian, Other and Other Mixed males.

The overall situation for females was slightly better with only 5 out of the 13 ethnic minority groups recording an unemployment rate in excess of 10 per cent in 2001. Some interesting anomalies are also observed for the mixed groups with Mixed: White \& Black Caribbean females experiencing the lowest employment rate amongst the mixed groups despite the high employment rates for the White and Black Caribbean groups individually, whilst the Mixed group labelled White \& Asians had the highest rate out of all of the Mixed and Other groups even though some of the 
Asian groups experienced very low levels of employment. The factors underlying the employment rates of the mixed ethnicity groups are complex. For example, the social and cultural implications of belonging to, or declaring, a mixed ethnicity are likely to be important (Mansaray, 2003). How these factors interact in the determination of employment outcomes for mixed race individuals is an area where further research is required.

Pooled probit estimates for males and females including dummy variables for the 15 ethnic dummies (relative to the excluded category of White British) are presented in Table A3. This specification exploits the greater detail on explanatory variables available in the 2001 sample. First, more detailed definitions are available for some of the variables that were present in 1991 such as marital status, ill health, children in the household and educational qualifications. For this latter variable there is now a 6 category breakdown as opposed to a single higher education identifier in the 1991 sample. Second, we have included a vector of dummy variables representing the individual's religion. A question on the religion of household members was included for the first time in the 2001 Census. Recent research has analysed the linkages between religion and economic outcomes. Barro and McCleary (2003) suggest that at the macroeconomic level the average level of religious belief is positively associated with a country's economic growth. They argue that "higher religious beliefs stimulate growth because they help to sustain aspects of individual behaviour that enhance productivity" (p. 39). Guiso et al. (2003) analyse religion and "economic" attitudes towards such things as thriftiness, the market economy and working women. They conclude that the strength of religious beliefs are associated with attitudes favouring 
higher national income but are also associated with racist beliefs and negative attitudes towards female participation in the labour market.

Finally, we have included the Index of Multiple Deprivation (IMD), a summary statistic used by the UK government to measure disadvantage at local area level along dimensions including income, employment, health, education, housing and crime. While the magnitude of the IMD has no natural interpretation and is scaled to lie between 0 and 100, we include it to reflect the idea that unobservable local area effects have an impact on the employment prospects of ethnic minority individuals over and above their personal characteristics. Clark and Drinkwater (2002) have explored similar issues for minorities in the UK, finding that area level effects influence labour market outcomes even when controlling for individual characteristics.

From Table A3 it is clear that the more detailed information available in the 2001 Census provides additional explanatory power in the employment probits. For both males and females, higher levels of qualifications monotonically increase employment probabilities with the high marginal effects of qualifications for females, relative to the excluded category of no qualifications, particularly noticeable. The additional dummy variables providing more detail on family composition and health status are also statistically significant.

Turning to religion, compared to those with no religion, we find that Sikh and Hindu males and Buddhists of both sexes experienced significantly lower employment 
probabilities. ${ }^{14}$ Furthermore, while Jewish males were significantly more likely to be in employment than Christians, the opposite was true for females. Christians, comprising the majority of our sample, were more likely to be in employment than those with no religious affiliation, while those who refused to answer the religion question on the Census form had significantly lower employment probabilities than those who declared themselves to have no religion. By far the biggest effect from the religion dummy variables, however, was for Muslims where males and females had employment rates which were significantly lower, in both economic and statistical senses, than the excluded category. This confirms the findings of Lindley (2002) who analyses data from the Fourth National Survey of Ethnic Minorities. Note, however, that in our pooled model, there is likely to be a high degree of correlation between religion and ethnicity and this may be influencing the results. In the pooled model, the IMD was also highly significant for males and females. The marginal effect is somewhat difficult to interpret given the nature of the variable, nonetheless it is clear that in areas which score highly on the deprivation scale individual employment probabilities are reduced.

Controlling for this extended list of characteristics it is still the case that males from all ethnic minority groups had a significantly lower employment rate than White British at the 5 per cent level. The probability of employment was significantly lower at the 5 per cent level for females from all minority groups apart from Indians, Black Caribbeans, Other Blacks and Chinese. Significant differences also remain between Whites and the Mixed and Other groups. These differences are particularly noticeable for Mixed: White \& Black Caribbean, Mixed: White \& Black Africans, Other Black

\footnotetext{
${ }^{14}$ The Census contains no information on religious devoutness or on how often an individual attends places of worship.
} 
and Other males. However, some of the differences between White Britons and the South Asian groups have been considerably attenuated in the 2001 pooled probit results compared to both the raw data and the less detailed specification reported in Table A1. Investigation reveals that this is due to the inclusion of religion in the current specification: the vast majority of Pakistanis and Bangladeshis are Muslims whilst nine out of ten Sikhs were from an Indian background, hence there is considerable collinearity between religion and ethnicity. Separate estimation of the model by ethnic group is necessary to obtain a more reliable estimate of the impact of religion.

Tables 8 and 9 report the marginal effects for religion, qualifications and the IMD from probit models estimated separately for each of the disaggregated ethnic groups and for males and females. Note that each probit contains the full set of explanatory variables, however we report only those effects relating to these three variables. For the religious effects, estimates are only reported if the cell size is at least $25 .{ }^{15}$ If the cell size is less than 25 then that particular religious category is subsumed within the Other category. Each of the religious effects is measured relative to those who stated that they had no religion. The results suggest that Muslim males were less likely to be employed than those with no religion in 11 out of the 13 groups which had adequate sample sizes, although these differences were statistically significant at the 10 per cent level or lower for 4 of the groups: White British, White Other, Pakistani and Other. The large (16 percentage points) penalty faced by White Muslims is particularly notable. Bangladeshi Muslims had an (insignificantly) higher probability of employment than those with no religion, although 93 per cent of Bangladeshis

\footnotetext{
${ }^{15}$ The only exceptions to this are Bangladeshi males and females, for whom the cell sizes are 15 and 12 respectively for the no religion category, which is the comparison group.
} 
described themselves as Muslims. Pakistani Christians were significantly less likely to be employed but Christians accounted for only 1 per cent of this ethnic group. The other religious effects were relatively small for males, with only a few significant differences. For example, despite the religious diversity amongst Indians, there are no significant employment differences compared to those with no religion.

Table 9 contains the results for females. Muslims had a lower employment rate for 12 out of the 13 groups, the exception being Other Blacks. The differences in employment rates between Muslims and those with no religion were in excess of 20 percentage points and significant at the 5 per cent level for 7 of the groups. The other religious effects were quite mixed for females: for example Christians had significantly higher employment rates for White British, Other Black, Mixed: White \& Black Caribbean and Other at the 10 per cent level but significantly lower rates for White Other, Other Mixed and Indians.

Tables 8 and 9 also reveal that qualifications had a positive, increasing and significant effect on employment for virtually all ethnic groups. The marginal effects for qualifications were also generally higher for ethnic minority groups than for the White British. For example, the employment advantage of Black African and Mixed: White \& Black African males with a higher education qualification (Level 4 or 5 qualifications) over those with no qualifications was more than 30 percentage points, compared to less than 10 percentage points for White British males. However, Level 1 and Level 2 qualifications (equivalent to 1 ' $A$ ' Level or lower) did not have a significant impact on the employment prospects of Chinese and Other Black males. For females the impact of human capital is again more important for most ethnic 
minority groups compared to White British, especially for those with Level 4/5 qualifications. For instance, Bangladeshi and Black African female graduates had an employment rate more than 40 percentage points higher than those with no qualifications, compared to an equivalent advantage of just over 20 percentage points for the White groups.

Table 8 reports that the IMD had a negative and significant impact on employment probabilities at the 5 per cent level for 13 of the 16 male groups. The exceptions being Other Mixed (significant at 10 per cent), Mixed: White \& Black African and Chinese, for whom employment rates are higher in more deprived areas. Whilst from Table 9 it can be seen that females from the majority of the groups had significantly higher employment rates in less deprived areas, with the biggest effects observed for Pakistani and Bangladeshi females. In a sense it is not surprising that for those in more deprived areas there are fewer employment opportunities for most groups. That there is ethnic diversity in the extent of this effect is more interesting. Whilst Whites also suffer lower employment rates in highly deprived areas the marginal effects are generally larger for ethnic minority groups. Given the disproportionate representation of minorities in relatively deprived, urban areas, the impact of the local area on employment, if not addressed by policy measures, has the potential to widen ethnic differences in labour market outcomes.

\section{Conclusions}

Over the period between the two population Censuses of 1991 and 2001, there was a general improvement in employment outcomes for ethnic minorities in England and Wales. Substantial reductions in the employment gap with Whites were observed for 
three of the most disadvantaged groups: Black African, Pakistani and Bangladeshi males. Moreover, the narrowing of the gap for these groups is attributable in part to increases in endowments of employment-enhancing characteristics, particularly educational qualifications. Other groups also experienced increased employment rates compared to Whites, however it would be misleading to suggest that such progress has eliminated ethnic employment disadvantage. First, in spite of increasing employment rates for most ethnic minority groups, large employment deficits with Whites remained in 2001, even for those groups whose employment rates had risen. Second, Black Caribbean males, whose educational attainment lags behind all other groups, largely failed to benefit from the general improvement in the labour market, when compared to Whites. Third, convergence between Whites and ethnic minorities was much less for females than for males and the position of females from some ethnic minority groups actually deteriorated. Fourth, Pakistani and Bangladeshi females continued to have extremely low employment rates in absolute terms - less than 30 per cent for each group in 2001.

The results of our comparative analysis of microdata from the two Censuses illustrate the complexity of the picture. Whilst some groups - notably Indian and Chinese males as well as Caribbean females - have employment rates broadly comparable with the White majority, others experience extremely large employment gaps. Whilst most groups have improved their relative position over the period, others lag behind. Furthermore, although human capital deficits explain some of the differences in employment rates, this is not the whole story - the decomposition results show that individuals with identical characteristics can experience quite difference employment probabilities and this may reflect discrimination in the labour market as well as 
between-group differences in labour supply behaviour related to tastes and preferences. The complexity of the picture implies that generalisations about the causes of ethnic gaps, or macro-level policy prescriptions which ignore the diversity of group-specific experiences, are unlikely to succeed.

Similarly, our analysis of responses to the 2001 Census emphasises the particular problems faced by ethnic minorities in terms of their geographical concentration in relatively deprived urban areas. It is well known that such concentration exists; what our results suggest is that the deprived nature of the local area is associated with lower employment rates, even when the impact of individual characteristics is held constant, and that the penalty associated with local deprivation varies by ethnic group. Clearly there may be problems inferring causality here: are areas deprived because of the (observable and unobservable) characteristics of those who live there or does the general level of economic activity in the area influence individual probabilities? There is a sense in which, from a policy perspective, which explanation is correct is not important: policy resources and measures targeted at particular types of area could have disproportionately beneficial effects for ethnic communities. To this extent the approach taken by the UK Government's Ethnic Minority Employment Task Force in "providing greater discretion and flexibility for local delivery bodies and improved targeting of resources in disadvantaged areas" (DWP, 2004, p.5) is to be endorsed.

Another key policy challenge concerns education: much of the improved employment performance of Pakistanis, Bangladeshis and Black Africans is due to younger cohorts of workers, many of whom are native born and who have invested in human capital, 
entering the labour market and reaping a return on their investment. Our results suggest that the returns to educational qualifications for ethnic minorities are substantially greater than those for Whites. This is a success story, however the challenge for the UK Government is to promulgate this success to the groups which, thus far, have not improved their skills and employability and which, consequently, still suffer severe disadvantage in the labour market.

Our regression models suggested that religion is an additional source of variation in labour market behaviour. In particular there is some evidence that, controlling for other factors, Muslims have lower employment rates than individuals with another, or indeed no, religion affiliation. Quantifying this is problematical for some of Britain's ethnic groups simply because ethnicity and religion are extremely highly correlated. Cultural attitudes and norms underlie some of the low employment rates, especially for Pakistani and Bangladeshi women, but separating the influences of ethnicity and religion is extremely difficult, both conceptually and empirically. It may also be misleading to label behaviour which is a potentially a choice as economic disadvantage. More interesting, and perhaps surprising, is that White Muslims experience an employment penalty, other things equal. Understanding the impact of religion in the UK labour market forms an important area for future research.

There are of course limits to how far government policy can impact on employment rates. Labour supply is driven by preferences as much as market incentives and some aspects of ethnicity or religion which reflect cultural differences may not be amenable to manipulation by the usual policy instruments. Indeed such manipulation may not be desirable hence a framework which is sensitive to culture is required. Equally 
though, in spite of around 30 years of anti-discrimination legislation, a significant body of empirical evidence leads inevitably to the conclusion that some amount of racial discrimination exists in the UK labour market. Such considerations suggest that ethnic employment differences are unlikely to be greatly reduced in the immediate future. 


\section{References}

Barro, R. and McCleary, J. (2003), "Religion and economic growth", NBER Working Paper No. 9682.

Battu, H., Mwale, M. and Zenou, Y. (2003), "Do oppositional identities reduce employment for ethnic minorities?", IZA Discussion Paper No. 721.

Battu, H., Seaman, P. and Zenou, Y. (2004), "Job contact networks and the ethnic minorities", IUI Working Paper No. 628, The Research Institute of Industrial Economics, Stockholm.

Blackaby, D. H., Clark, K., Leslie, D. G. and Murphy, P. D. (1994), "Black-white male earnings and employment prospects in the 1970s and 1980s: Evidence for Britain”, Economics Letters, 46, 273-279.

Blackaby, D. H., Drinkwater, S. J., Leslie, D. G. and Murphy, P. D., (1997), “A picture of male and female unemployment amongst ethnic minorities in Britain”, Scottish Journal of Political Economy, 44, 182-197.

Blackaby, D. H., Leslie, D. G., Murphy, P. D. and O’Leary, N. C. (1998), “The ethnic wage gap and employment differentials in the 1990s: Evidence from Britain”, Economics Letters, 58, 97-103.

Blackaby, D. H., Leslie, D. G., Murphy, P. D. and O’Leary, N. C. (1999), “Unemployment among Britain's ethnic minorities”, Manchester School, 67, 120.

Blackaby, D. H., Leslie, D. G., Murphy, P. D. and O'Leary, N. C. (2002), "White/ethnic minority and employment differentials in Britain: Evidence from the LFS", Oxford Economic Papers, 54, 270-297. 
Blackaby, D. H., Leslie, D. G., Murphy, P. D. and O'Leary, N. C. (2005), “Born in Britain: How are native ethnic minorities faring in the British labour market?", Economics Letters, forthcoming.

Brown, C. (1984), Black and White Britain, Heinemann, London.

Clark, K. and Drinkwater, S. (2002), "Enclaves, neighbourhood effects and economic outcomes: Ethnic minorities in England and Wales", Journal of Population Economics, 15, 5-29.

CRE (1996), We Regret to Inform You..., Commission for Racial Equality, London.

Daniel, W. (1968), Racial Discrimination in England, Penguin Books, Harmondsworth.

DWP (2001), UK Employment Action Plan 2001, Department for Work and Pensions, London.

[http://www.dwp.gov.uk/publications/dss/2001/eactpln/enap2k1.pdf]

DWP (2004), Equality. Opportunity. Success, Ethnic Minority Employment Task Force Year 1 Progress Report, Department of Work and Pensions, London. [http://www.emetaskforce.gov.uk/pdf/EMETF.pdf]

Disney, R. (1999), "Why have older men stopped working?" in P. Gregg and J. Wadsworth (eds), The State of Working Britain, Manchester University Press, Manchester.

Dustmann, C. and Fabbri, F. (2003), "Language proficiency and labour market performance of immigrants in the UK", Economic Journal, 113, 695-717.

Even, E. and Macpherson, D. (1993), "The decline of private-sector unionism and the gender wage gap", Journal of Human Resources, 28, 279-296.

Fritjers, P., Shields, M. A. and Wheatley Price, S. (2003), "Immigrant job search in the UK: Evidence from panel data”, IZA Discussion Paper No. 902. 
Gomulka, J and Stern, N (1990), “The employment of married women in the United Kingdom 1970-83, Economica, 57, 171-199.

Guiso, L, Sapienza, P. and Zingales, L. (2003), "People's opium? Religion and economic attitudes", Journal of Monetary Economics, 50, 225-282.

Holdsworth, C. and Dale, A. (1997), "Ethnic differences in women's employment", Work, Employment and Society, 11, 435-457.

Leslie, D. (1998) (ed.), An Investigation of Racial Disadvantage, Manchester University Press, Manchester.

Leslie, D. and Drinkwater, S. (1999), "Staying on in full-time education: Reasons for higher participation rates among ethnic minority males and females", Economica, 66, 63-77.

Leslie, D. and Lindley, J. (2001), “The impact of language ability on employment and earnings of Britain's ethnic communities”, Economica, 68, 587-606.

Lindley, J. (2002), "Race or religion? The impact of religion on the employment and earnings of Britain's ethnic communities", Journal of Ethnic and Migration Studies, 28, 427-442.

Mansaray, A. (2003), "Review Essay: The alchemy of mixed race", The Global Review of Ethnopolitics, 2, 100-106.

Oaxaca, R. (1973), "Male-female wage differentials in urban labor markets", International Economic Review, 14, 693-709.

OECD (2003), "Statistical Annex", in OECD Employment Outlook 2003, Organisation for Economic Cooperation and Development, Paris.

Shields, M. A. and Wheatley Price, S. (2001), "Language fluency and immigrant employment prospects: Evidence from Britain's ethnic minorities", Applied Economics Letters, 8, 741-745. 
Smith, D. J. (1976), The Facts of Racial Disadvantage: A National Survey, Political and Economic Planning, London.

Simpson, L. and Akinwale, B. (2004), "Quantifying stability and change in ethnic group", mimeo, Centre for Census and Survey Research, University of Manchester. [http://www.ccsr.ac.uk/staff/Ludi/documents/JOSstability.pdf]

Thomas, J. M. (1998a), "Ethnic variation in commuting propensity and unemployment spells: Some UK evidence", Journal of Urban Economics, 43, 385-400.

Thomas, J. M. (1998b), "Who feels it knows it: Work attitudes and excess non-white unemployment in the UK", Ethnic and Racial Studies, 21, 138-150.

Wheatley Price, S. (2001a), "The employment adjustment of male immigrants in England", Journal of Population Economics, 14, 193-220.

Wheatley Price, S. (2001b), “The unemployment experience of male immigrants in England", Applied Economics, 33, 201-215. 
Table 1. Population by Ethnic Group and Age: 1991- 2001

\begin{tabular}{|c|c|c|c|c|c|c|c|c|c|c|c|c|c|c|c|}
\hline & \multicolumn{4}{|c|}{1991} & \multicolumn{4}{|c|}{2001} & \multicolumn{3}{|c|}{$\begin{array}{l}\text { Percentage Point } \\
\text { Change 1991-2001 }\end{array}$} & \multicolumn{4}{|c|}{ Growth Rates 1991-2001 } \\
\hline & $0-15$ & 16-64 & $65+$ & Total & $0-15$ & 16-64 & $65+$ & Total & $0-15$ & 16-64 & $65+$ & $0-15$ & 16-64 & $65+$ & Total \\
\hline White & 19.26 & 63.81 & 16.93 & $46,937,861$ & 19.20 & 63.79 & 17.01 & $47,520,866$ & -0.05 & -0.02 & 0.07 & 0.97 & 1.21 & 1.67 & 1.24 \\
\hline Black Caribbean & 21.89 & 72.46 & 5.64 & 499,030 & 20.36 & 69.02 & 10.62 & 563,843 & -1.53 & -3.44 & 4.97 & 5.08 & 7.62 & 112.55 & 12.99 \\
\hline Black African & 29.38 & 69.13 & 1.48 & 209,589 & 30.18 & 67.50 & 2.32 & 479,665 & 0.79 & -1.63 & 0.84 & 135.02 & 123.47 & 7258.29 & 128.86 \\
\hline Indian & 29.54 & 66.39 & 4.07 & 830,205 & 22.89 & 70.50 & 6.61 & $1,036,807$ & -6.65 & 4.11 & 2.55 & -3.24 & 32.61 & 103.06 & 24.89 \\
\hline Pakistani & 42.81 & 55.44 & 1.75 & 455,363 & 34.98 & 60.83 & 4.19 & 714,826 & -7.83 & 5.39 & 2.43 & 28.28 & 72.25 & 275.14 & 56.98 \\
\hline Bangladeshi & 47.29 & 51.51 & 1.20 & 161,701 & 38.44 & 58.33 & 3.23 & 280,830 & -8.85 & 6.83 & 2.03 & 41.15 & 96.69 & 367.66 & 73.67 \\
\hline Chinese & 23.15 & 73.41 & 3.44 & 146,462 & 18.33 & 76.55 & 5.13 & 226,948 & -4.83 & 3.14 & 1.69 & 22.63 & 61.58 & 131.17 & 54.95 \\
\hline All Ethnic Minorities & 33.02 & 63.73 & 3.25 & $2,952,416$ & 30.14 & 64.74 & 5.12 & $4,521,050$ & -2.88 & 1.01 & 1.87 & 39.76 & 55.56 & 141.40 & 53.13 \\
\hline Total & 20.07 & 63.81 & 16.12 & $49,890,277$ & 20.15 & 63.87 & 15.97 & $52,041,916$ & 0.08 & 0.07 & -0.15 & 4.75 & 4.42 & 3.34 & 4.31 \\
\hline
\end{tabular}

Sources: 1991 and 2001 Censuses of Population.

Note: The figures for All Ethnic Minorities include other and mixed ethnic groups, which are not reported separately in the table. 
Table 2. Labour Market Activity by Broad Ethnic Group: 1991-2001

\begin{tabular}{|c|c|c|c|c|c|c|c|c|c|c|}
\hline & \multicolumn{5}{|c|}{ Male } & \multicolumn{4}{|c|}{ Female } & \multirow[b]{2}{*}{$\begin{array}{c}\text { Sample } \\
\text { Size }\end{array}$} \\
\hline & $\begin{array}{c}\text { Activity } \\
\text { Rate }\end{array}$ & $\begin{array}{l}\text { Emp. } \\
\text { Rate }\end{array}$ & $\begin{array}{c}\text { Emp. Rate } \\
\text { (no students) }\end{array}$ & $\begin{array}{c}\text { Unemp. } \\
\text { Rate }\end{array}$ & $\begin{array}{c}\text { Sample } \\
\text { Size }\end{array}$ & $\begin{array}{l}\text { Activity } \\
\text { Rate }\end{array}$ & $\begin{array}{l}\text { Emp. } \\
\text { Rate }\end{array}$ & $\begin{array}{c}\text { Emp. Rate } \\
\text { (no students) }\end{array}$ & $\begin{array}{c}\text { Unemp. } \\
\text { Rate }\end{array}$ & \\
\hline \multicolumn{11}{|c|}{$\begin{array}{ll}1991 \\
\end{array}$} \\
\hline White & 86.1 & 76.8 & 81.1 & 10.9 & 297,205 & 67.3 & 62.9 & 67.0 & 6.5 & 274,501 \\
\hline Black Caribbean & 84.7 & 63.4 & 66.8 & 25.1 & 3,220 & 72.3 & 63.1 & 67.9 & 12.7 & 3,473 \\
\hline Black African & 64.8 & 45.8 & 62.6 & 29.4 & 1,372 & 56.2 & 42.4 & 52.2 & 24.6 & 1,354 \\
\hline Indian & 81.4 & 69.8 & 78.8 & 14.2 & 5,455 & 59.1 & 51.7 & 57.9 & 12.6 & 5,206 \\
\hline Pakistani & 73.7 & 50.8 & 59.7 & 31.0 & 2,585 & 26.6 & 18.6 & 20.8 & 30.3 & 2,333 \\
\hline Bangladeshi & 73.1 & 48.5 & 56.4 & 33.7 & 922 & 20.0 & 12.4 & 14.1 & 38.1 & 776 \\
\hline Chinese & 65.9 & 58.4 & 81.6 & 11.5 & 1,095 & 53.1 & 49.3 & 64.4 & 7.1 & 1,085 \\
\hline All Ethnic Minorities & 77.5 & 61.0 & 70.9 & 21.3 & 18,420 & 54.7 & 46.4 & 53.0 & 15.2 & 18,012 \\
\hline \multicolumn{11}{|c|}{2001} \\
\hline White & 82.3 & 77.5 & 81.1 & 5.8 & 467,739 & 71.9 & 68.8 & 71.8 & 4.3 & 432,473 \\
\hline Black Caribbean & 77.5 & 64.5 & 68.9 & 16.8 & 5,361 & 72.8 & 66.1 & 71.0 & 9.3 & 6,239 \\
\hline Black African & 71.7 & 59.2 & 72.0 & 17.4 & 4,818 & 60.1 & 50.0 & 58.8 & 16.8 & 5,136 \\
\hline Indian & 77.4 & 71.3 & 80.5 & 7.9 & 11,087 & 63.7 & 59.2 & 65.2 & 7.2 & 10,746 \\
\hline Pakistani & 68.0 & 57.0 & 66.4 & 16.2 & 6,810 & 31.0 & 25.4 & 27.4 & 18.0 & 6,541 \\
\hline Bangladeshi & 68.6 & 54.7 & 63.3 & 20.3 & 2,586 & 27.9 & 21.4 & 22.2 & 23.0 & 2,430 \\
\hline Chinese & 64.8 & 60.1 & 82.4 & 7.3 & 2,579 & 56.7 & 52.4 & 66.7 & 7.7 & 2,754 \\
\hline All Ethnic Minorities & 72.3 & 62.7 & 72.9 & 13.2 & 43,962 & 56.1 & 50.0 & 56.0 & 10.9 & 44,762 \\
\hline
\end{tabular}

Sources: Individual Sample of Anonymised Records (SARs) from the 1991 Census and Controlled Access Microdata (CAMs) from the 2001 Census.

Notes: Sample size relates to working age population (16-59/64). The All Ethnic Minorities category also includes those ethnic minority groups not in the table i.e. the other and mixed categories. 
Table 3. Difference in Differences in Labour Market Outcomes, relative to Whites: 1991-2001

\begin{tabular}{|c|c|c|c|c|}
\hline \multicolumn{5}{|c|}{ Male } \\
\hline & Activity & Employment & Employment (no students) & Unemployment \\
\hline Black Caribbean & $-0.033^{* * *}$ & 0.003 & $0.021^{* *}$ & $-0.032^{* * *}$ \\
\hline Black African & $0.107^{* * *}$ & $0.126^{* * *}$ & $0.094^{* * *}$ & $-0.069^{* * *}$ \\
\hline Indian & -0.001 & 0.008 & $0.018^{* *}$ & $-0.013^{* * *}$ \\
\hline Pakistani & $-0.017^{* *}$ & $0.055^{* * *}$ & $0.070^{* * *}$ & $-0.098^{* * *}$ \\
\hline Bangladeshi & -0.003 & $0.058^{* * *}$ & $0.073^{* * *}$ & $-0.085^{* * *}$ \\
\hline Chinese & $0.026^{* *}$ & 0.009 & 0.008 & 0.008 \\
\hline All Ethnic Minorities & $-0.013^{* * *}$ & $0.011^{* * *}$ & $0.021^{* * *}$ & $-0.030^{* * *}$ \\
\hline \multicolumn{5}{|c|}{ Female } \\
\hline & Activity & Employment & Employment (no students) & Unemployment \\
\hline Black Caribbean & $-0.042^{* * *}$ & $-0.030^{* * * *}$ & $-0.017^{*}$ & $-0.013^{* *}$ \\
\hline Black African & -0.006 & 0.018 & 0.016 & $-0.055^{* * *}$ \\
\hline Indian & 0.000 & $0.016^{* *}$ & $0.024^{* * *}$ & $-0.032^{* * *}$ \\
\hline Pakistani & -0.002 & 0.010 & 0.017 & $-0.100^{* * *}$ \\
\hline Bangladeshi & $0.033^{*}$ & 0.031 & 0.032 & $-0.126^{* * *}$ \\
\hline Chinese & -0.009 & $-0.028^{*}$ & -0.025 & $0.028^{* * *}$ \\
\hline All Ethnic Minorities & $-0.033^{* * *}$ & $-0.024^{* * *}$ & $-0.018^{* * *}$ & $-0.020^{* * *}$ \\
\hline
\end{tabular}

Sources: 1991 SARs and 2001 Individual Licensed SARs.

Note: Data relate to working age population. There may be slight differences compared to Table 2 because of rounding and because the

Individual Licensed SARs is used here rather than the CAMs. ${ }^{*} p<0.1 ;{ }^{* *} p<0.05 ;{ }^{* * *} p<0.01$ (two-tailed tests). Significance tests are based on standard errors computed from a regression on pooled 1991 and 2001 data where the dependent variable was the labour market outcome and the explanatory variables included a "treatment" (ethnicity) dummy, a time dummy and an interaction between the preceding two variables. 
Table 4. Male Probit Decompositions of the Employment Differential with Whites: 1991 and 2001

\begin{tabular}{|c|c|c|c|c|c|c|}
\hline \multicolumn{7}{|c|}{1991} \\
\hline & $\begin{array}{c}\text { Black } \\
\text { Caribbean }\end{array}$ & $\begin{array}{c}\text { Black } \\
\text { African }\end{array}$ & Indian & Pakistani & Bangladeshi & Chinese \\
\hline Differences in means & 0.142 & 0.186 & 0.024 & 0.214 & 0.248 & -0.005 \\
\hline Differences in coefficients & 0.073 & 0.176 & 0.032 & 0.155 & 0.137 & 0.020 \\
\hline Differences in characteristics & 0.070 & 0.010 & -0.008 & 0.059 & 0.111 & -0.025 \\
\hline \multicolumn{7}{|l|}{ Characteristics breakdown: } \\
\hline Age & 0.006 & -0.016 & -0.024 & -0.008 & 0.010 & -0.021 \\
\hline Higher qualifications & 0.010 & -0.007 & -0.005 & 0.007 & 0.009 & -0.015 \\
\hline Marital status & 0.023 & 0.005 & -0.030 & -0.021 & -0.019 & -0.013 \\
\hline Dependant children & -0.001 & 0.001 & 0.010 & 0.011 & 0.013 & 0.004 \\
\hline Immigrant status & 0.015 & 0.017 & 0.048 & 0.045 & 0.038 & 0.033 \\
\hline Region & 0.012 & 0.014 & -0.005 & 0.005 & 0.025 & 0.007 \\
\hline Ill health & 0.005 & -0.005 & -0.001 & 0.021 & 0.035 & -0.020 \\
\hline \multicolumn{7}{|c|}{2001} \\
\hline & $\begin{array}{c}\text { Black } \\
\text { Caribbean }\end{array}$ & $\begin{array}{c}\text { Black } \\
\text { African }\end{array}$ & Indian & Pakistani & Bangladeshi & Chinese \\
\hline Differences in means & 0.122 & 0.092 & 0.007 & 0.147 & 0.180 & -0.013 \\
\hline Differences in coefficients & 0.081 & 0.107 & 0.021 & 0.125 & 0.147 & 0.018 \\
\hline Differences in characteristics & 0.041 & -0.015 & -0.014 & 0.022 & 0.033 & -0.031 \\
\hline \multicolumn{7}{|l|}{ Characteristics breakdown: } \\
\hline Age & -0.011 & -0.065 & -0.015 & -0.018 & -0.021 & -0.029 \\
\hline Higher qualifications & 0.004 & -0.039 & -0.011 & -0.002 & 0.002 & -0.021 \\
\hline Marital status & 0.019 & -0.004 & -0.019 & -0.023 & -0.021 & -0.010 \\
\hline Dependant children & -0.000 & 0.000 & -0.000 & 0.001 & 0.001 & 0.000 \\
\hline Immigrant status & 0.021 & 0.101 & 0.038 & 0.049 & 0.049 & 0.065 \\
\hline Region & 0.005 & 0.023 & -0.004 & 0.005 & 0.016 & 0.001 \\
\hline Ill health & 0.003 & -0.031 & -0.003 & 0.009 & 0.007 & -0.036 \\
\hline
\end{tabular}

Notes: Students are excluded. Data relate to working age population. 
Table 5. Female Probit Decompositions of the Employment Differential with Whites: 1991 and 2001

\begin{tabular}{|c|c|c|c|c|c|c|}
\hline \multicolumn{7}{|c|}{1991} \\
\hline & $\begin{array}{c}\text { Black } \\
\text { Caribbean }\end{array}$ & $\begin{array}{c}\text { Black } \\
\text { African }\end{array}$ & Indian & Pakistani & Bangladeshi & Chinese \\
\hline Differences in means & -0.008 & 0.148 & 0.092 & 0.463 & 0.531 & 0.027 \\
\hline Differences in coefficients & -0.047 & 0.087 & -0.007 & 0.266 & 0.291 & -0.002 \\
\hline Differences in characteristics & 0.039 & 0.061 & 0.099 & 0.198 & 0.239 & 0.029 \\
\hline \multicolumn{7}{|l|}{ Characteristics breakdown: } \\
\hline Age & -0.001 & -0.026 & -0.016 & -0.006 & -0.002 & -0.022 \\
\hline Higher qualifications & 0.001 & -0.017 & 0.005 & 0.017 & 0.021 & -0.024 \\
\hline Marital status & -0.018 & -0.009 & 0.007 & 0.007 & 0.008 & 0.002 \\
\hline Dependant children & 0.010 & 0.035 & 0.058 & 0.097 & 0.115 & 0.031 \\
\hline Immigrant status & 0.016 & 0.040 & 0.037 & 0.066 & 0.055 & 0.048 \\
\hline Region & 0.019 & 0.037 & 0.001 & 0.002 & 0.027 & 0.011 \\
\hline Ill health & 0.012 & 0.001 & 0.008 & 0.015 & 0.017 & -0.016 \\
\hline \multicolumn{7}{|c|}{2001} \\
\hline & $\begin{array}{c}\text { Black } \\
\text { Caribbean }\end{array}$ & $\begin{array}{c}\text { Black } \\
\text { African }\end{array}$ & Indian & Pakistani & Bangladeshi & Chinese \\
\hline Differences in means & 0.008 & 0.131 & 0.067 & 0.445 & 0.497 & 0.052 \\
\hline Differences in coefficients & -0.039 & 0.067 & 0.012 & 0.298 & 0.301 & 0.042 \\
\hline Differences in characteristics & 0.031 & 0.064 & 0.054 & 0.147 & 0.197 & 0.010 \\
\hline \multicolumn{7}{|l|}{ Characteristics breakdown: } \\
\hline Age & -0.020 & -0.029 & -0.015 & -0.011 & -0.009 & -0.018 \\
\hline Higher qualifications & -0.010 & -0.027 & -0.016 & 0.007 & 0.015 & -0.028 \\
\hline Marital status & 0.005 & 0.001 & -0.002 & -0.001 & -0.002 & -0.001 \\
\hline Dependant children & 0.014 & 0.026 & 0.022 & 0.051 & 0.065 & 0.008 \\
\hline Immigrant status & 0.025 & 0.064 & 0.053 & 0.081 & 0.079 & 0.061 \\
\hline Region & 0.023 & 0.039 & 0.005 & 0.004 & 0.036 & 0.011 \\
\hline Ill health & 0.004 & -0.009 & 0.007 & 0.016 & 0.014 & -0.023 \\
\hline
\end{tabular}

Notes: Students are excluded. Data relate to working age population. 
Table 6. Means of key characteristics: 1991 and 2001

\begin{tabular}{|c|c|c|c|c|c|c|}
\hline \multicolumn{7}{|c|}{ Males } \\
\hline & \multicolumn{3}{|c|}{1991} & \multicolumn{3}{|c|}{2001} \\
\hline & Age & Higher quals & UK born & Age & Higher quals & UK born \\
\hline White & 39.385 & 0.167 & 0.954 & 41.160 & 0.210 & 0.949 \\
\hline Black Caribbean & 38.381 & 0.057 & 0.441 & 39.796 & 0.153 & 0.546 \\
\hline Black African & 34.737 & 0.300 & 0.233 & 37.776 & 0.506 & 0.190 \\
\hline Indian & 38.084 & 0.205 & 0.151 & 39.414 & 0.376 & 0.272 \\
\hline Pakistani & 37.268 & 0.098 & 0.152 & 36.242 & 0.236 & 0.273 \\
\hline Bangladeshi & 38.668 & 0.081 & 0.068 & 34.976 & 0.174 & 0.134 \\
\hline Chinese & 38.050 & 0.300 & 0.096 & 39.433 & 0.417 & 0.174 \\
\hline \multicolumn{7}{|c|}{ Females } \\
\hline & \multicolumn{3}{|c|}{1991} & \multicolumn{3}{|c|}{2001} \\
\hline & Age & Higher quals & UK born & Age & Higher quals & UK born \\
\hline White & 37.410 & 0.139 & 0.950 & 39.384 & 0.214 & 0.942 \\
\hline Black Caribbean & 36.135 & 0.134 & 0.446 & 38.154 & 0.281 & 0.587 \\
\hline Black African & 33.187 & 0.235 & 0.222 & 36.139 & 0.402 & 0.183 \\
\hline Indian & 36.090 & 0.110 & 0.147 & 37.555 & 0.324 & 0.272 \\
\hline Pakistani & 34.184 & 0.040 & 0.183 & 33.953 & 0.167 & 0.313 \\
\hline Bangladeshi & 35.352 & 0.015 & 0.081 & 32.609 & 0.111 & 0.144 \\
\hline Chinese & 36.828 & 0.264 & 0.081 & 38.712 & 0.413 & 0.134 \\
\hline
\end{tabular}


Table 7. Labour Market Activity by Narrow Ethnic Groups: 2001

\begin{tabular}{|c|c|c|c|c|c|c|c|c|c|c|}
\hline & \multicolumn{5}{|c|}{ Male } & \multicolumn{5}{|c|}{ Female } \\
\hline & $\begin{array}{c}\text { Activity } \\
\text { Rate }\end{array}$ & $\begin{array}{l}\text { Emp. } \\
\text { Rate }\end{array}$ & $\begin{array}{c}\text { Emp. Rate } \\
\text { (no students) }\end{array}$ & $\begin{array}{c}\text { Unemp. } \\
\text { Rate }\end{array}$ & $\begin{array}{c}\text { Sample } \\
\text { Size }\end{array}$ & $\begin{array}{c}\text { Activity } \\
\text { Rate }\end{array}$ & $\begin{array}{l}\text { Emp. } \\
\text { Rate }\end{array}$ & $\begin{array}{c}\text { Emp. Rate } \\
\text { (no students) }\end{array}$ & $\begin{array}{c}\text { Unemp. } \\
\text { Rate }\end{array}$ & $\begin{array}{c}\text { Sample } \\
\text { Size }\end{array}$ \\
\hline \multicolumn{11}{|l|}{ White } \\
\hline White British & 82.5 & 77.8 & 81.2 & 5.7 & 446,470 & 72.2 & 69.1 & 72.0 & 4.2 & 410,539 \\
\hline White Irish & 76.1 & 71.0 & 73.4 & 6.8 & 6,616 & 70.4 & 67.0 & 69.5 & 4.9 & 5,993 \\
\hline Other White & 76.5 & 71.2 & 80.6 & 7.0 & 14,653 & 65.4 & 61.2 & 67.9 & 6.4 & 15,941 \\
\hline \multicolumn{11}{|l|}{ Mixed } \\
\hline Mixed: Whi. \& Bla. Car. & 73.7 & 60.7 & 68.8 & 17.6 & 1,365 & 62.0 & 53.2 & 60.1 & 14.2 & 1,531 \\
\hline Mixed: Whi. \& Bla. Afr. & 70.9 & 55.4 & 64.0 & 21.8 & 662 & 60.2 & 54.3 & 60.6 & 9.8 & 659 \\
\hline Mixed: Whi. \& Asian & 70.9 & 64.2 & 77.5 & 9.4 & 1,410 & 62.2 & 57.1 & 65.2 & 8.2 & 1,354 \\
\hline Other Mixed & 69.6 & 61.1 & 73.6 & 12.2 & 1,187 & 61.6 & 55.6 & 65.1 & 9.8 & 1,314 \\
\hline \multicolumn{11}{|l|}{ Other } \\
\hline Other Asian & 72.2 & 64.5 & 73.6 & 10.7 & 3,048 & 54.9 & 49.8 & 55.7 & 9.3 & 2,193 \\
\hline Other Black & 72.5 & 58.7 & 67.8 & 19.1 & 808 & 66.9 & 57.0 & 64.2 & 14.7 & 917 \\
\hline Other & 63.6 & 55.7 & 71.3 & 12.4 & 2,241 & 52.1 & 47.4 & 55.5 & 9.0 & 2,948 \\
\hline
\end{tabular}

Sources: 2001 CAMs.

Note: Sample sizes relate to working age population. Figures for the remaining ethnic groups are reported in Table 2. 
Table 8. Selected Marginal Effects for the Probability of Being in Employment, Males: 2001

\begin{tabular}{|c|c|c|c|c|c|c|c|c|c|c|c|c|c|c|c|c|}
\hline & $\begin{array}{l}\text { White } \\
\text { British }\end{array}$ & $\begin{array}{l}\text { White } \\
\text { Irish }\end{array}$ & $\begin{array}{l}\text { White } \\
\text { Other }\end{array}$ & $\begin{array}{c}\text { Mixed: } \\
\text { W\&B.C. }\end{array}$ & $\begin{array}{l}\text { Mixed: } \\
\text { W\&B.A. }\end{array}$ & $\begin{array}{l}\text { Mixed: } \\
\text { W\&As. }\end{array}$ & $\begin{array}{l}\text { Other } \\
\text { Mixed }\end{array}$ & Indian & Pakist. & Bangla. & $\begin{array}{l}\text { Other } \\
\text { Asian }\end{array}$ & $\begin{array}{l}\text { Black } \\
\text { Carib. }\end{array}$ & $\begin{array}{c}\text { Black } \\
\text { African }\end{array}$ & $\begin{array}{l}\text { Other } \\
\text { Black }\end{array}$ & Chinese & Other \\
\hline Christian & $0.018^{* * * *}$ & 0.012 & 0.009 & 0.001 & 0.102 & 0.038 & -0.019 & -0.003 & $-0.291^{* * * * 4}$ & - & -0.024 & $0.039^{*}$ & 0.023 & 0.082 & -0.029 & $-0.081^{*}$ \\
\hline Buddhist & $-0.053^{* * *}$ & - & -0.052 & - & - & - & - & - & - & - & 0.054 & - & - & - & -0.032 & -0.041 \\
\hline Hindu & -0.064 & - & & - & _- & - & - & 0.031 & - & - & 0.063 & - & - & - & - & - \\
\hline Jewish & $0.041^{\text {*** }}$ & - & -0.011 & - & - & - & - & - & - & - & - & - & - & - & - & - \\
\hline Muslim & $-0.159^{* * *}$ & - & $-0.194^{* * * *}$ & - & -0.138 & -0.048 & -0.081 & -0.032 & $-0.118^{*}$ & 0.079 & -0.051 & -0.049 & -0.055 & 0.045 & - & $-0.289^{* * *}$ \\
\hline Sikh & $-0.127^{*}$ & - & - & - & - & - & - & 0.008 & - & - & 0.027 & - & - & - & - & - \\
\hline Other & 0.009 & -0.025 & -0.012 & -0.028 & -0.005 & 0.048 & $0.142^{* * * *}$ & 0.040 & $-0.307 * *$ & 0.135 & $0.175^{* * * *}$ & $-0.108^{*}$ & 0.007 & 0.032 & -0.048 & -0.121 \\
\hline $\begin{array}{l}\text { Religion } \\
\text { not stated }\end{array}$ & -0.008 & $-0.103^{* * *}$ & $-0.041^{* * * *}$ & -0.045 & 0.086 & $-0.112^{*}$ & -0.117 & -0.000 & $-0.153^{*}$ & 0.015 & -0.003 & 0.023 & 0.010 & -0.021 & $-0.070^{* *}$ & $-0.225^{* * * *}$ \\
\hline $\begin{array}{l}\text { Level } 1 \\
\text { quals }\end{array}$ & $0.073^{3}$ & $0.062^{2 *}$ & $0.075^{* * 2}$ & 0.206 & $0.204^{\text {N7\%? }}$ & $0.139^{2}$ & 0.146 & $0.064^{\text {a }}$ & $0.104^{\text {stw }}$ & 0.078 & 0.039 & $0.162^{\text {* }}$ & 0.160 & 0.027 & 0.025 & $0.096^{\text {*F }}$ \\
\hline $\begin{array}{l}\text { Level } 2 \\
\text { quals }\end{array}$ & $0.082^{* * *}$ & $0.096^{* * * *}$ & $0.077^{\text {**** }}$ & $0.249^{* * * *}$ & $0.211^{* * *}$ & $0.165^{* * * *}$ & $0.186^{* * *}$ & $0.070^{* * * *}$ & $0.129^{* * *}$ & $0.144^{* * * *}$ & $0.095^{* * * *}$ & $0.182^{* * * *}$ & $0.213^{* * *}$ & 0.054 & 0.021 & $0.112^{\text {*** }}$ \\
\hline $\begin{array}{l}\text { Level } 3 \\
\text { quals }\end{array}$ & $0.091^{* * *}$ & $0.136^{* * * *}$ & $0.080^{* * * *}$ & $0.275^{* * * *}$ & $0.229^{* * * *}$ & $0.124^{* * *}$ & $0.172^{* * *}$ & $0.081^{* * * *}$ & $0.168^{* * * *}$ & $0.208^{* * * *}$ & $0.147^{\text {**** }}$ & $0.185^{* * * *}$ & $0.204^{* * * *}$ & $0.114^{*}$ & $0.052^{*}$ & $0.075^{* *}$ \\
\hline $\begin{array}{l}\text { Level } 4 / 5 \\
\text { quals }\end{array}$ & $0.099^{* * *}$ & $0.160^{* * * *}$ & $0.142^{* * * *}$ & $0.249^{* * * *}$ & $0.342^{* * * *}$ & $0.221^{* * * *}$ & $0.214^{* * * *}$ & $0.150^{* * * *}$ & $0.218^{* * * *}$ & $0.233^{* * * *}$ & $0.185^{\text {**** }}$ & $0.219^{\text {**** }}$ & $0.304^{* * * *}$ & $0.165^{* * * *}$ & $0.104^{* * * *}$ & $0.217^{* * * *}$ \\
\hline $\begin{array}{l}\text { Other } \\
\text { quals }\end{array}$ & $0.069^{\text {**** }}$ & $0.108^{* * * *}$ & $0.076^{* * * *}$ & $0.189^{* * * *}$ & $0.217^{* * * *}$ & $0.117^{* * * *}$ & 0.041 & $0.049^{* * * *}$ & $0.066^{* *}$ & $0.087^{*}$ & $0.099^{* * * *}$ & $0.106^{* * * *}$ & $0.155^{* * * *}$ & $-0.277^{* * * *}$ & $0.076^{* * * *}$ & $0.082^{* *}$ \\
\hline IMD/100 & -0.066 & -0.107 & -0.163 & -0.338 & -0.141 & -0.201 & -0.161 & -0.072 & $-0.351^{*}$ & $-0.138^{\prime}$ & -0.359 & -0.153 & -0.318 & -0.225 & 0.027 & -0.263 \\
\hline $\mathrm{N}$ & 416,391 & 6,285 & 12,527 & 1,099 & 528 & 1,072 & 903 & 9,306 & 5,515 & 2,077 & 2,510 & 4,832 & 3,542 & 661 & 1,723 & 1,632 \\
\hline
\end{tabular}

Notes: Controls also included age, marital status, children in household, region, health and immigrant status. All students are excluded from the analysis. Data relate to working age population. ${ }^{*} p<0.1 ;{ }^{* *} p<0.05 ;{ }^{* * *} p<0.01$ (two-tailed tests). 
Table 9. Selected Marginal Effects for the Probability of Being in Employment, Females: 2001

\begin{tabular}{|c|c|c|c|c|c|c|c|c|c|c|c|c|c|c|c|c|}
\hline & $\begin{array}{l}\text { White } \\
\text { British }\end{array}$ & $\begin{array}{l}\text { White } \\
\text { Irish }\end{array}$ & $\begin{array}{l}\text { White } \\
\text { Other }\end{array}$ & $\begin{array}{c}\text { Mixed: } \\
\text { W\&B.C. }\end{array}$ & $\begin{array}{l}\text { Mixed: } \\
\text { W\&B.A. }\end{array}$ & $\begin{array}{l}\text { Mixed: } \\
\text { W\&As. }\end{array}$ & $\begin{array}{l}\text { Other } \\
\text { Mixed }\end{array}$ & Indian & Pakist. & Bangla. & $\begin{array}{l}\text { Other } \\
\text { Asian }\end{array}$ & $\begin{array}{l}\text { Black } \\
\text { Carib. }\end{array}$ & $\begin{array}{c}\text { Black } \\
\text { African }\end{array}$ & $\begin{array}{l}\text { Other } \\
\text { Black }\end{array}$ & Chinese & Other \\
\hline Christian & $0.029^{* * * *}$ & -0.017 & $-0.040^{\text {**** }}$ & $0.115^{\text {***** }}$ & 0.056 & 0.016 & $-0.088^{* * *}$ & $-0.097^{*}$ & 0.129 & - & 0.015 & 0.037 & -0.033 & $0.150^{* * *}$ & 0.019 & $0.180^{* * * *}$ \\
\hline Buddhist & $-0.063^{\text {**** }}$ & - & $-0.184^{* *}$ & - & - & - & - & - & - & - & 0.073 & - & - & - & -0.002 & -0.015 \\
\hline Hindu & -0.105 & - & - & - & - & - & - & -0.034 & - & - & -0.017 & - & - & - & - & $0.272^{* * *}$ \\
\hline Jewish & $-0.036^{* * *}$ & - & $-0.055^{*}$ & 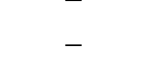 & - & - & - & - & - & - & - & - & - & - & - & - \\
\hline Muslim & $-0.203^{\text {**** }}$ & 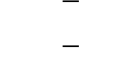 & $-0.275^{\text {**** }}$ & - & -0.128 & $-0.256^{* * *}$ & $-0.248^{* * * *}$ & $-0.307^{* * *}$ & -0.008 & $-0.459^{* *}$ & $-0.150^{*}$ & -0.011 & $-0.248^{\text {**** }}$ & 0.018 & - & -0.030 \\
\hline $\begin{array}{l}\text { Sikh } \\
\text { Other }\end{array}$ & $\begin{array}{c}0.008 \\
-0.010\end{array}$ & $-0 . \overline{141} 1^{* *}$ & -0.035 & $0 . \overline{-}^{* * *}$ & $0 . \overline{1} 54$ & $-0 . \overline{0} 49$ & $-0 . \overline{1} 07$ & $\begin{array}{l}-0.026 \\
-0.007\end{array}$ & $0 . \overline{108}$ & $-0.129^{* * * *}$ & $\begin{array}{c}0.139 \\
-0.002\end{array}$ & $0 . \overline{0} 80$ & $-0 . \overline{104}$ & $-0 . \overline{1} 44$ & $-0 . \overline{0} 10$ & $0 . \overline{063}$ \\
\hline $\begin{array}{l}\text { Religion } \\
\text { not stated }\end{array}$ & -0.008 & $-0.079^{*}$ & $-0.054^{* * * *}$ & 0.057 & -0.004 & $-0.207^{\text {*** }}$ & -0.064 & -0.083 & -0.004 & $-0.145^{* * * *}$ & -0.095 & -0.013 & $-0.137^{*}$ & $0.142^{* *}$ & -0.005 & 0.011 \\
\hline $\begin{array}{l}\text { Level } 1 \\
\text { quals }\end{array}$ & $0.131^{3 \times w 4}$ & 0.106 & $0.107^{\text {; }}$ & 0.256 & 0.100 & 0.100 & $0.162^{* * * 6-}$ & 0.125 & $0.207^{-1}$ & $0.222^{* * * *}$ & $0.117^{\text {\$Pक }}$ & 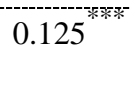 & $0.207^{* x^{*}}$ & $0.204^{\text {*\$* }}$ & 0.127 & 0.069 \\
\hline $\begin{array}{l}\text { Level } 2 \\
\text { quals }\end{array}$ & $0.175^{* * * *}$ & $0.164^{* * * *}$ & $0.154^{* * * *}$ & $0.253^{* * * *}$ & $0.284^{* * *}$ & $0.205^{* * *}$ & $0.225^{* * * *}$ & $0.200^{* * *}$ & $0.308^{* * *}$ & $0.296^{* * * *}$ & $0.235^{* * * *}$ & $0.148^{* * *}$ & $0.295^{* * * *}$ & $0.250^{* * * *}$ & $0.057^{*}$ & $0.113^{* * *}$ \\
\hline $\begin{array}{l}\text { Level } 3 \\
\text { quals }\end{array}$ & $0.193^{* * * *}$ & $0.171^{* * * *}$ & $0.144^{* * * *}$ & $0.332^{* * * *}$ & $0.218^{* * * *}$ & $0.265^{* * *}$ & $0.229^{* * * *}$ & $0.182^{* * *}$ & $0.389^{* * *}$ & $0.318^{* * * *}$ & $0.320^{* * * *}$ & $0.176^{* * *}$ & $0.303^{\text {**** }}$ & $0.296^{* * * *}$ & $0.142^{* * *}$ & $0.147^{* * *}$ \\
\hline $\begin{array}{l}\text { Level } 4 / 5 \\
\text { quals }\end{array}$ & $0.219^{* * * *}$ & $0.242^{* * *}$ & $0.210^{* * * *}$ & $0.349^{* * * *}$ & $0.319^{* * * *}$ & $0.265^{* * *}$ & $0.279^{* * * *}$ & $0.187^{* * *}$ & $0.325^{* * *}$ & $0.454^{* * *}$ & $0.349^{* * * *}$ & $0.227^{* * *}$ & $0.401^{* * *}$ & $0.324^{* * * *}$ & $0.164^{* * * *}$ & $0.169^{\text {*** }}$ \\
\hline $\begin{array}{l}\text { Other } \\
\text { quals }\end{array}$ & $0.111^{* * * *}$ & $0.109^{* * *}$ & $0.138^{* * * *}$ & $0.237^{\text {**** }}$ & $0.288^{* * * *}$ & -0.061 & $0.235^{* * * *}$ & $0.136^{* * * *}$ & $0.163^{* * *}$ & $0.290^{* * * *}$ & $0.161^{* * * *}$ & $0.097^{* * *}$ & $0.177^{* * * *}$ & $0.243^{* * * *}$ & 0.027 & 0.075 \\
\hline IMD/100 & $-0.112^{\text {**⿻一未丷 }}$ & 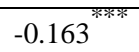 & $-0.052^{*}$ & 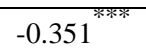 & -0.074 & $-0.321^{\text {米* }}$ & $-0.238^{* *}$ & $-0.151^{* * * * *}$ & $-0.455^{\text {**** }}$ & $-0.389^{* \text { **** }}$ & 0.027 & 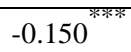 & $-0.315^{\text {****** }}$ & -0.005 & -0.070 & -0.048 \\
\hline $\mathrm{N}$ & 377,911 & 5,565 & 13,602 & 1,207 & 513 & 1,068 & 1,011 & 9,087 & 5,525 & 2,035 & 1,826 & 5,507 & 3,824 & 759 & 1,958 & 2,356 \\
\hline
\end{tabular}

Notes: Controls also included age, marital status, children in household, region, health and immigrant status. All students are excluded from the analysis. Data relate to working age population. ${ }^{*} p<0.1 ;{ }^{* *} p<0.05 ;{ }^{* * *} p<0.01$ (two-tailed tests). 


\section{DATA APPENDIX}

\section{Ethnic Group}

The Ethnicity question in the 1991 Census asked the person to tick the appropriate box from the following options:

0 White

1 Black-Caribbean

2 Black-African

Black-Other (please describe)

3 Indian

4 Pakistani

5 Bangladeshi

6 Chinese

Any other ethnic group (please describe)

The question also stated that "If the person is descended from more than one ethnic or racial group, please tick the group which the person considers he/she belongs, or tick the 'Any other ethnic group' box and describe the person's ancestry in the space provided".

The Ethnicity question in the 2001 Census asked the person to choose ONE section from $\mathrm{A}$ to $\mathrm{E}$, then tick the appropriate box to indicate their cultural background:

A White

British

Irish

Any other White background (please write in)

B Mixed

White and Black Caribbean

White and Black African

White and Asian

Any other Mixed background (please write in)

C Asian or Asian British

Indian

Pakistani

Bangladeshi

Any other Asian background (please write in)

D Black or Black British

Caribbean

African

Any other Black background (please write in)

E Chinese or other ethnic group

Chinese

Any other (please write in) 


\section{Economic Activity}

The Economic Activity question in the 1991 Census asked which of the following things was the person doing last week (more than one option could be chosen):

1 Was working for an employer full time (more than 30 hours a week)

2 Was working for an employer part time (one hour or more a week)

3 Was self-employed, employing other people

4 Was self-employed, not employing other people

5 Was on a government employment or training scheme

6 Was waiting to start a job he/she had already accepted

7 Was unemployed and looking for a job

8 Was at school or in full time education

9 Was unable to work because of long term sickness or disability

10 Was retired from paid work

11 Was looking after the home or family

Other (please specify)

From the responses to these question, the following categories were created to described the respondent's primary economic position in the 1991 SARs:

1 Full-time employee

2 Part-time employee

3 Self-employed, with employees

4 Self-employed, no employees

5 On a government scheme

6 Unemployed

7 Student

8 Permanently sick

9 Retired

10 Other

In Table 2, the economic outcomes were derived from the above categories as follows:

Activity Rate $=((1+2+3+4+5+6) /(1+2+3+4+5+6+7+8+9+10)) * 100$

Employment Rate $=((1+2+3+4+5) /(1+2+3+4+5+6+7+8+9+10)) * 100$

Employment Rate $($ no students $)=((1+2+3+4+5) /(1+2+3+4+5+6+8+9+10)) * 100$

Unemployment Rate $=(6 /(1+2+3+4+5+6)) * 100$

The following Economic Activity questions were asked in the 2001 Census:

18. Last week, were you doing any paid work:

- as an employee, or on a Government sponsored scheme,

- as a self-employed/freelance, or in your own/family business 
(Tick 'Yes' if away from work ill, on maternity leave, on holiday or temporarily laid off. Tick 'Yes' for any paid work, including casual or temporary work, even if for only one hour. Tick 'Yes' if you worked, paid or unpaid, in your own/family business.)

Yes $=>$ go to Question 24

No $=>$ go to Question 19

19. Were you actively looking for any kind of work during the last 4 weeks?

Yes or No.

20. If a job had been available last week, could you have started it within 2 weeks?

Yes or No.

21. Last week, were you waiting to start a job already obtained?

Yes or no.

22. Last week, were you any of the following? (tick all the boxes that apply)

Retired

Student

Looking after home/family

Permanently sick/disabled

None of the above

The change in the nature of the economic activity questions to some extent reflected the intention to make the statistics compatible with the ILO definition of economic status.

From the responses to these questions, the following categories could be identified in the 2001 SARs:

1 Employee part-time

2 Employee full-time

3 Self-employed with employees - part-time

4 Self-employed with employees - full-time

5 Self-employed without employees - part-time

6 Self-employed without employees - full-time

7 Unemployed, seeking work and available to start within 2 weeks

8 Unemployed, waiting to start a job already obtained and available to start within 2 weeks

9 Retired

10 Student (not economically active)

11 Looking after the home or family

12 Permanently sick or disabled

13 Other

Students who were economically active were coded in categories 1-8 above if they reported that they did some form of economic activity. 
In Tables 2 and 3, the economic outcomes were derived from the above questions as follows:

Activity Rate $=((1+2+3+4+5+6+7+8) /(1+2+3+4+5+6+7+8+9+10+11+12+13)) * 100$

Employment Rate $=((1+2+3+4+5+6) /(1+2+3+4+5+6+7+8+9+10+11+12+13)) * 100$

Employment Rate (no students) $=((1+2+3+4+5+6) /$

$(1+2+3+4+5+6+7+8+9+11+12+13)) * 100$

N. B. All full-time students are removed from both the numerator and denominator under this definition i.e. economically active students are excluded from this definition.

Unemployment Rate $=((7+8) /(1+2+3+4+5+6+7+8)) * 100$

\section{Information on selected explanatory variables}

Higher qualifications: An individual was identified as having a higher qualification in 1991 if they responded that they had any post-school qualification. In 2001, those with Level 4 or Level 5 qualifications were deemed to have a higher qualification.

Qualification levels in 2001:

Level 1: 1+ 'O' level passes; 1+ CSE/GCSE any grades; NVQ level 1; Foundation GNVQ.

Level 2: 5+ 'O' level passes; 5+ CSE (grade 1); 5+ GCSEs (grades A-C); School Certificate; 1+ 'A' Levels/AS levels; NVQ level 2; Intermediate GNVQ.

Level 3: 2+ 'A' Levels; 4+ AS levels; Higher School certificate; NVQ Level 3; Advanced GNVQ.

Level 4/5: First degree; Higher degree; NVQ Levels 4 and 5; HNC; HND; Qualified teacher status; Qualified medical doctor; Qualified dentist; Qualified nurse; Midwife; Health visitor.

Dependent children in household: In both years, residents of communal establishments were defined as having no dependent children in their household.

Index of Multiple Deprivation (IMD): Published by the Office of the Deputy Prime Minister, 2004. The IMD is constructed using seven Super Output Area level Domain Indicies. These domains are income deprivation; employment deprivation; health deprivation \& disability; education, skills \& training deprivation; barriers to housing \& services; crime and living environment deprivation. The indicators used to construct the domains generally relate to 2001. It should be noted that the IMD scores for England and Wales are constructed slightly differently. The IMD is only available in the CAMs since no local authority identifiers are present in the 2001 Individual Licensed SARs, which is available through the Cathie Marsh Centre for Census and Survey Research at the University of Manchester. 
Table A1. Probit Estimates of Employment Incidence: 1991

\begin{tabular}{lcccccccc}
\hline \hline & \multicolumn{3}{c}{ Males } & & \multicolumn{3}{c}{ Females } \\
\cline { 2 - 5 } \cline { 8 - 9 } & Mean & M. E. & S. E. & & Mean & M. E. & S. E. \\
\hline Age & 39.316 & 0.023 & 0.000 & & 37.318 & 0.038 & 0.001 \\
Age Squared/100 & 17.211 & -0.034 & 0.001 & & 15.314 & 0.054 & 0.001 \\
Married & 0.620 & 0.119 & 0.003 & & 0.647 & -0.073 & 0.003 \\
Divorced/Widowed & 0.072 & -0.002 & 0.003 & & 0.106 & -0.095 & 0.004 \\
Dependant children in household & 0.377 & -0.024 & 0.002 & & 0.460 & -0.267 & 0.002 \\
Higher qualifications & 0.167 & 0.082 & 0.002 & & 0.138 & 0.159 & 0.002 \\
UK Born & 0.923 & 0.021 & 0.004 & & 0.916 & 0.045 & 0.004 \\
Black Caribbean & 0.010 & -0.078 & 0.008 & & 0.012 & 0.054 & 0.009 \\
Black African & 0.003 & -0.218 & 0.017 & & 0.004 & -0.106 & 0.017 \\
Indian & 0.016 & -0.053 & 0.007 & & 0.017 & 0.003 & 0.008 \\
Pakistani & 0.007 & -0.209 & 0.012 & & 0.008 & -0.359 & 0.012 \\
Bangladeshi & 0.003 & -0.161 & 0.019 & & 0.003 & -0.401 & 0.021 \\
Chinese & 0.003 & -0.034 & 0.016 & & 0.003 & -0.005 & 0.018 \\
North East & 0.062 & -0.007 & 0.004 & & 0.062 & 0.014 & 0.005 \\
Yorkshire and Humberside & 0.098 & 0.019 & 0.003 & & 0.097 & 0.036 & 0.005 \\
East Midlands & 0.081 & 0.043 & 0.003 & & 0.081 & 0.047 & 0.005 \\
East Anglia & 0.041 & 0.064 & 0.003 & & 0.040 & 0.043 & 0.006 \\
Inner London & 0.046 & -0.020 & 0.005 & & 0.049 & -0.035 & 0.006 \\
Outer London & 0.081 & 0.049 & 0.003 & & 0.084 & 0.035 & 0.005 \\
South East & 0.214 & 0.065 & 0.003 & & 0.213 & 0.047 & 0.004 \\
South West & 0.092 & 0.048 & 0.003 & & 0.090 & 0.039 & 0.005 \\
West Midlands & 0.105 & 0.039 & 0.003 & & 0.104 & 0.038 & 0.005 \\
North West & 0.125 & 0.009 & 0.003 & & 0.125 & 0.037 & 0.005 \\
Limiting long term illness & 0.101 & -0.491 & 0.003 & & 0.077 & -0.457 & 0.003 \\
\hline Pseudo R & & 0.213 & & & & 0.120 & \\
\hline N & & 293,928 & & & 270,611 & \\
\hline \hline & & & & & & \\
\hline
\end{tabular}

Notes: Default categories are single, no dependant children in household, born overseas, no higher qualifications, White and Wales. Students are excluded from the analysis. Table reports marginal effects and heteroscedasticity robust standard errors as well as the means of the explanatory variables. 
Table A2. Probit Estimates of Employment Incidence: 2001

\begin{tabular}{|c|c|c|c|c|c|c|}
\hline & \multicolumn{3}{|c|}{ Males } & \multicolumn{3}{|c|}{ Females } \\
\hline & Mean & M. E. & S. E. & Mean & M. E. & S. E. \\
\hline Age & 40.992 & 0.024 & 0.000 & 39.194 & 0.035 & 0.001 \\
\hline Age Squared/100 & 18.406 & -0.035 & 0.000 & 16.644 & -0.048 & 0.001 \\
\hline Married & 0.561 & 0.113 & 0.002 & 0.581 & 0.009 & 0.002 \\
\hline Divorced/Widowed & 0.094 & 0.024 & 0.002 & 0.129 & -0.000 & 0.003 \\
\hline Dependant children in household & 0.348 & 0.001 & 0.001 & 0.450 & -0.177 & 0.002 \\
\hline Higher qualifications & 0.215 & 0.063 & 0.001 & 0.219 & 0.136 & 0.002 \\
\hline UK Born & 0.911 & 0.040 & 0.003 & 0.901 & 0.086 & 0.003 \\
\hline Black Caribbean & 0.010 & -0.098 & 0.007 & 0.013 & 0.032 & 0.006 \\
\hline Black African & 0.008 & -0.162 & 0.009 & 0.009 & -0.085 & 0.009 \\
\hline Indian & 0.020 & -0.040 & 0.005 & 0.021 & -0.014 & 0.006 \\
\hline Pakistani & 0.012 & -0.184 & 0.008 & 0.013 & -0.385 & 0.008 \\
\hline Bangladeshi & 0.004 & -0.202 & 0.012 & 0.005 & -0.382 & 0.013 \\
\hline Chinese & 0.004 & -0.035 & 0.011 & 0.005 & -0.047 & 0.012 \\
\hline North East & 0.049 & -0.015 & 0.003 & 0.049 & -0.009 & 0.004 \\
\hline North West & 0.129 & 0.013 & 0.003 & 0.129 & 0.025 & 0.003 \\
\hline Yorkshire and the Humber & 0.095 & 0.025 & 0.003 & 0.095 & 0.031 & 0.004 \\
\hline East Midlands & 0.082 & 0.043 & 0.002 & 0.081 & 0.034 & 0.004 \\
\hline West Midlands & 0.101 & 0.035 & 0.002 & 0.100 & 0.027 & 0.004 \\
\hline East of England & 0.106 & 0.065 & 0.002 & 0.105 & 0.033 & 0.004 \\
\hline South East & 0.156 & 0.069 & 0.002 & 0.154 & 0.041 & 0.003 \\
\hline South West & 0.094 & 0.054 & 0.002 & 0.093 & 0.034 & 0.004 \\
\hline Inner London & 0.052 & 0.009 & 0.003 & 0.055 & -0.039 & 0.005 \\
\hline Outer London & 0.081 & 0.050 & 0.002 & 0.085 & 0.019 & 0.004 \\
\hline Limiting long term illness & 0.153 & -0.460 & 0.002 & 0.133 & -0.447 & 0.002 \\
\hline Pseudo $\mathrm{R}^{2}$ & \multicolumn{3}{|c|}{0.251} & \multicolumn{3}{|c|}{0.144} \\
\hline $\mathrm{N}$ & \multicolumn{3}{|c|}{462,198} & \multicolumn{3}{|c|}{425,013} \\
\hline
\end{tabular}

Notes: Default categories are single, no dependant children in household, born overseas, no higher qualifications, White and Wales. Regions are slightly different to Table A1 because of the regional boundary changes that took place between 1991 and 2001. All students are excluded from the analysis. Table reports marginal effects and heteroscedasticity robust standard errors as well as the means of the explanatory variables. 
Table A3. Probit Estimates of Employment Incidence, Detailed Specification: 2001

\begin{tabular}{|c|c|c|c|c|c|c|}
\hline & \multicolumn{3}{|c|}{ Males } & \multicolumn{3}{|c|}{ Females } \\
\hline & Mean & M.E. & S. E. & Mean & M.E. & S. E. \\
\hline Age & 40.913 & 0.026 & 0.000 & 39.128 & 0.036 & 0.001 \\
\hline Age squared/100 & 18.340 & -0.036 & 0.000 & 16.590 & -0.047 & 0.001 \\
\hline Married & 0.455 & 0.116 & 0.002 & 0.465 & 0.005 & 0.002 \\
\hline Remarried & 0.081 & 0.092 & 0.002 & 0.080 & 0.020 & 0.003 \\
\hline Separated & 0.024 & 0.045 & 0.003 & 0.036 & -0.022 & 0.004 \\
\hline Divorced & 0.085 & 0.036 & 0.002 & 0.109 & 0.016 & 0.003 \\
\hline Widowed & 0.009 & 0.026 & 0.005 & 0.019 & -0.068 & 0.006 \\
\hline Only dep. Children in household & 0.325 & 0.001 & 0.001 & 0.427 & -0.209 & 0.002 \\
\hline Non-dep. Children in household & 0.024 & -0.006 & 0.004 & 0.024 & -0.082 & 0.005 \\
\hline Dep. and non-dep. children & 0.023 & 0.025 & 0.003 & 0.021 & 0.029 & 0.005 \\
\hline Level 1 qualifications & 0.191 & 0.076 & 0.001 & 0.199 & 0.137 & 0.002 \\
\hline Level 2 qualifications & 0.183 & 0.086 & 0.001 & 0.220 & 0.183 & 0.002 \\
\hline Level 3 qualifications & 0.073 & 0.095 & 0.001 & 0.078 & 0.201 & 0.002 \\
\hline Level 4/5 qualifications & 0.218 & 0.109 & 0.001 & 0.221 & 0.229 & 0.002 \\
\hline Other qualifications & 0.092 & 0.071 & 0.001 & 0.047 & 0.118 & 0.003 \\
\hline UK Born & 0.902 & 0.003 & 0.003 & 0.890 & 0.047 & 0.004 \\
\hline White Irish & 0.013 & -0.031 & 0.006 & 0.013 & 0.005 & 0.007 \\
\hline Other White & 0.027 & -0.054 & 0.005 & 0.031 & -0.065 & 0.006 \\
\hline Mixed: Whi. \& Bla. Car. & 0.002 & -0.125 & 0.014 & 0.003 & -0.087 & 0.014 \\
\hline Mixed: Whi. \& Bl. Afr. & 0.001 & -0.181 & 0.022 & 0.001 & -0.079 & 0.022 \\
\hline Mixed: Whi. \& Asian & 0.002 & -0.049 & 0.013 & 0.002 & -0.069 & 0.016 \\
\hline Other Mixed & 0.002 & -0.091 & 0.016 & 0.002 & -0.056 & 0.016 \\
\hline Indian & 0.020 & -0.018 & 0.008 & 0.021 & -0.003 & 0.010 \\
\hline Pakistani & 0.012 & -0.045 & 0.008 & 0.013 & -0.141 & 0.011 \\
\hline Bangladeshi & 0.004 & -0.065 & 0.011 & 0.005 & -0.143 & 0.016 \\
\hline Other Asian & 0.005 & -0.083 & 0.011 & 0.004 & -0.061 & 0.014 \\
\hline Black Caribbean & 0.010 & -0.109 & 0.007 & 0.013 & 0.019 & 0.007 \\
\hline Black African & 0.008 & -0.185 & 0.010 & 0.009 & -0.085 & 0.009 \\
\hline Other Black & 0.001 & -0.144 & 0.019 & 0.002 & -0.036 & 0.018 \\
\hline Chinese & 0.004 & -0.031 & 0.011 & 0.005 & -0.018 & 0.012 \\
\hline Other Ethnic Group & 0.003 & -0.131 & 0.013 & 0.005 & -0.116 & 0.012 \\
\hline
\end{tabular}




\section{Table A3 (Continued)}

\begin{tabular}{lcccccc}
\hline Christian & 0.682 & 0.018 & 0.002 & 0.737 & 0.028 & 0.002 \\
Buddhist & 0.003 & -0.030 & 0.011 & 0.003 & -0.050 & 0.014 \\
Hindu & 0.011 & -0.013 & 0.009 & 0.011 & 0.031 & 0.011 \\
Jewish & 0.005 & 0.037 & 0.008 & 0.005 & -0.036 & 0.011 \\
Muslim & 0.027 & -0.115 & 0.008 & 0.027 & -0.180 & 0.009 \\
Sikh & 0.006 & -0.046 & 0.012 & 0.007 & 0.050 & 0.012 \\
Other religion & 0.018 & 0.009 & 0.004 & 0.010 & -0.006 & 0.008 \\
Religion not stated & 0.073 & -0.014 & 0.003 & 0.063 & -0.014 & 0.003 \\
North East & 0.048 & -0.013 & 0.003 & 0.049 & -0.005 & 0.004 \\
North West & 0.128 & 0.015 & 0.002 & 0.128 & 0.026 & 0.003 \\
Yorkshire and the Humber & 0.094 & 0.032 & 0.002 & 0.094 & 0.040 & 0.004 \\
East Midlands & 0.081 & 0.046 & 0.002 & 0.080 & 0.035 & 0.004 \\
West Midlands & 0.101 & 0.043 & 0.002 & 0.099 & 0.031 & 0.004 \\
East of England & 0.105 & 0.066 & 0.002 & 0.104 & 0.026 & 0.004 \\
South East & 0.155 & 0.066 & 0.002 & 0.154 & 0.028 & 0.003 \\
South West & 0.093 & 0.050 & 0.002 & 0.092 & 0.023 & 0.004 \\
Inner London & 0.055 & 0.024 & 0.003 & 0.058 & -0.021 & 0.005 \\
Outer London & 0.084 & 0.054 & 0.002 & 0.089 & 0.019 & 0.004 \\
In fairly good health & 0.207 & -0.118 & 0.002 & 0.240 & -0.110 & 0.002 \\
In not good health & 0.085 & -0.531 & 0.003 & 0.081 & -0.464 & 0.003 \\
Index of Multiple Deprivation/100 & 0.212 & -0.079 & 0.003 & 0.215 & -0.127 & 0.005 \\
\hline Pseudo R & & 0.239 & & & 0.159 & \\
\hline N & 470,603 & & & 433,754 & \\
\hline \hline
\end{tabular}

Notes: Default categories are single, no children in household, born overseas, no qualifications, White British, no religion, Wales and in good health. All full-time students have been excluded from the analysis. The table contains marginal effects and heteroscedasticity robust standard errors as well as the means of the explanatory variables. 